\title{
Non-random lizard extinctions in land-bridge Amazonian forest islands after 28 years of isolation
}

5

10

Key-words: habitat fragmentation, hydroelectric dams, reptiles, species-area relationship, thermoregulation, trait-environment relationship

\section{Introduction}

Hydropower development is currently one of the primary means of habitat loss and fragmentation in lowland tropical forests, hence a key threat to biodiversity (World Commission on Dams, 2000; Lees et al., 2016; Winemiller et al., 2016). River damming a Laboratório de Vertebrados, Departamento de Ecologia, Universidade Federal do Rio de Janeiro, CP 68020, Rio de Janeiro RJ, CEP 21941-590, Brazil

${ }^{\mathrm{b}}$ Centre for Ecology, Evolution and Conservation, School of Environmental Sciences, University of East Anglia, Norwich NR4 7TJ, UK.

* Corresponding author. Address: Laboratório de Vertebrados, Departamento de Ecologia, Universidade Federal do Rio de Janeiro, CP 68020, Rio de Janeiro RJ, CEP 21941-590, Brazil. E-mail address: anafilipapalmeirim@gmail.com

Short title: Lizard extinctions in land-bridge Amazonian islands
Major hydropower infrastructure has become a leading driver of biodiversity loss in the and tropics. Terrestrial species typically become stranded in post-isolation landbridge islands within hydroelectric reservoirs. Understanding the resulting extinction dynamics of insular communities is critical to inform, if not to avert, the ongoing blitzkrieg of dam development. Here we assess the effects of forest patch and landscape metrics on diurnal lizard species richness and composition within the Balbina (ne Central Brazilian Amazon. This 28-yrplaced along stream banks. We further related morpho-ecological traits of lizard species to the spatial metrics of islands where they occurred. Using 100L-pitfall traps operated over 5447 trap-days, we recorded 1123 lizards from 17 taxa, two of which exclusively found along stream banks within continuous forest. Island area was the best predictor of species richness and composition. Small islands ( $\leq 2 \mathrm{ha}$ ) harboured fewer than a third of all species typically observed in larger islands and continuous forest ( $\geq 8$ species), and only islands $\geq 100$ ha retained nearly complete lizard faunas. Lizard assemblages inhabiting small, isolated islands consisted almost exclusively of an oversimplified set of large-bodied, habitat generalist, heliophile species associated with open areas and forest edges, and that feed on a wide spectrum of prey sizes. These wholesale changes in lizard community structure were characterized by severe losses in functional traits, and may profoundly affect ecosystem functioning. 
inundates low elevation areas while previous ridgetops in undulating terrain often become land-bridge islands, creating complex archipelagic landscapes within reservoirs. Currently, this is the case of at least 14 mega hydroelectric dams worldwide (Jones et al., 2016). In lowland Amazonia, due to the typically flat relief, damming further creates proportionally shallow lakes that are prone to siltation, flooding vast areas and emitting high levels of greenhouse gases (Fearnside and Pueyo, 2012). Nevertheless, Amazonia is now one of the main target regions for ambitious hydropower development plans (Zarf et al., 2015). To date, 191 dams have already been built and another 246 are planned or under construction (Lees et al., 2016).

In the aftermath of damming, the aquatic realm becomes widely degraded (Palmeirim et al., 2014; Macedo and Castello, 2015), while terrestrial habitats become extremely reduced and highly fragmented. Species diversity in newly created landbridge islands are likely to be affected by both the remaining area, which constrains species population sizes and limits habitat diversity (Hutchinson, 1957; MacArthur and Wilson, 1967), and degree of isolation from other islands and mainland, which affects species colonization rates (MacArthur and Wilson, 1967). Also, given the increased wind damage, edge effects penetrate deeply into the islands, modifying its vegetation structure and precluding changes in trophic and structural resources availability (Laurance et al., 1998; Benchimol and Peres, 2015a). Moreover, species responses to habitat fragmentation largely depend on the intrinsic ecological traits of different species (Cabrera-Guzman and Reynoso, 2012; Lion et al., 2016). For example, it is expected that forest-dependent animal species tend to disappear from structurally degraded islands (Benchimol and Venticinque, 2014). Identifying those traits that predispose species to extinction following fragmentation has important implications for proactive conservation management (Wang et al., 2009; Carvajal-Cogollo and UrbinaCardona, 2015).

Our knowledge to date on the ecological impacts of reservoir creation is disproportionately focussed on mammals, while lizards have been considered in only one-tenth of all impact studies (Jones et al., 2016). Yet lizards, and reptiles in general, include the most threatened and least studied terrestrial vertebrate taxa (IUCN, 2015) and their global scale declines have been mainly attributed to habitat loss and 80 degradation, including habitat fragmentation (Gardner et al., 2007a; Todd et al., 2010; $\mathrm{B} \square \mathrm{hm}$ et al., 2013). Lizards are ectothermic, are often specialized on a substrate type, and typically exhibit low dispersal capacity (Garda et al., 2013), all of which render them dependent on specific microhabitats and climatic conditions. They play important roles in natural ecosystems as predators, prey, grazers, seed dispersers and commensal species. Also, due to their specific microhabitat associations, lizards are thought to be good ecological indicators of habitat quality (Silva, 2005; Todd et al., 2010).

Amazonian lizard communities are usually rich and structurally complex (Martins, 1991). Individual species are separated on the basis of food and microhabitat types, which are closely linked to their metabolism (Vitt et al., 1999). Two thermoregulation modes or strategies to maintain their body temperature can be recognized for diurnal lizards: heliophile species that expose themselves to direct sunflecks, and heliophobe species that, instead, avoid direct exposure to sun light (Martins, 1991; Vitt et al., 1998). Warm-adapted lizards also tend to be larger-bodied and feed on a variety of arthropods and smaller vertebrates (Vitt et al., 1998), usually corresponding to generalist species.

Here we assess the influence of forest patch and landscape metrics on the species richness and composition of insular lizard assemblages within Balbina Hydroelectric Dam of Central Brazilian Amazonia. Balbina reservoir comprises an area of 443 772-ha, 
including 3546 land-bridge forest islands. This study was carried out following a 28year island post-isolation history and uncovers processes that could occur in similar artificial archipelagic landscapes that are currently proliferating throughout the Amazon (Lees et al., 2016). Along the island size gradient, we further examined (1) species abundance and biomass, considering species with contrasting thermoregulation modes separately; (2) the corresponding rank-abundance distribution curves; and (3) the relationships between morpho-ecological traits of lizard species and the spatial metrics of sites where they occurred. Overall, we predicted that 'sun-loving', large-bodied species with generalist habits were likely to dominate highly disturbed small forest islands, whereas the diversity of all functional groups should only accumulate in considerably larger islands and continuous forest sites, because those will also include 110 shade-tolerant, small-bodied specialists.

\section{Methods}

\subsection{Study landscape}

115 This study was carried out in the archipelagic landscape of the Balbina Hydroelectric Reservoir and its surrounding mainland areas in the Central Brazilian Amazon $\left(1^{\circ} 48^{\prime} \mathrm{S}\right.$, 59²9'W; Fig. 1). The Balbina Dam was built in 1987 on the Uatumã River, a left-bank tributary of Amazon River. Given the typically undulating topography of the inundated area, this dam flooded a vast area, with its reservoir comprising an area of 443 772-ha

120 (FUNCATE/INPE/ANEEL, 2000). In the aftermath of damming, the former hilltops of the pre-inundation forest area were converted into 3546 land-bridge islands widely distributed throughout the reservoir lake. Although some islands are large (e.g. 4860 and 4878 ha), most of them are relatively small, with 94.7\% smaller than 100 ha (Fig. 1). Within the wider open-water matrix, dead relics of large canopy trees still remain standing, as the vegetation of the submerged area was never cleared, except for the area immediately adjacent to the dam. As the inundated landscape matches lower elevation areas, most of which corresponded to riparian areas prior to damming, this habitat type virtually vanished from entire archipelago. The mean annual temperature in this region is $28^{\circ} \mathrm{C}$ and the mean annual rainfall is $2376 \mathrm{~mm}$ (IBAMA, 1997). The area within and

130 around the former left bank of the Uatumã river was legally protected since the dam was built by the 942 786-hectare Uatumã Biological Reserve, the largest reserve in its category in Brazil. This reserve largely explains the reasonably low levels of postdamming anthropogenic disturbance throughout the study landscape.

Terrestrial diurnal lizard assemblages were sampled at 25 islands previously selected according to its size, isolation and spatial distribution, so a wide range of island configurations within the reservoir could be accomplished. Sampled islands ranged in island area from 0.83 to 1466 ha (Table A.1) and distances to continuous forest (CF) from 10 to $11885 \mathrm{~m}$. We further sampled five sites (i.e. blocks of trapping-arrays) within four CF regions that were widely distributed in the adjacent mainland (Fig. 1).

140 Three of the sites were placed within $1500 \mathrm{~m}$ from reservoir margin $\left(\mathrm{CF}_{1}, \mathrm{CF}_{3}\right.$ and $\left.\mathrm{CF}_{4}\right)$ and two farther than $2000 \mathrm{~m}\left(\mathrm{CF}_{2}\right.$ and $\left.\mathrm{CF}_{2 \text {-riparian }}\right)$. These two additional sites were located in the same region, but one was positioned alongside riparian forest habitat along a $\sim 7 \mathrm{~m}$-wide perennial stream. Due to logistic constraints, riparian habitat could not be sampled at other CF regions, so that our $\mathrm{CF}$ samples consist of four upland sites that matched the topography of island samples $\left(\mathrm{CF}_{1}-\mathrm{CF}_{4}\right)$ and one riparian site $\left(\mathrm{CF}_{2}\right.$ riparian).

\subsection{Lizard sampling}


At each sampling site, trapping plots consisting of a 60-m long array of three pitfall arrays (buckets of $100 \mathrm{~L}$ in volume), which were spaced at $20-\mathrm{m}$ intervals and connected by a $50-\mathrm{cm}$ high plastic fence, with $10-\mathrm{m}$ of overhanging fence farther extended after the two external pitfalls. An additional $10-\mathrm{cm}$ of plastic fencing was buried underground, thereby deterring leaf-litter lizards from crossing the pitfall-trap-line. The number of trapping plots placed at each site ranged proportionally to its area. Due to spatial restrictions in small islands, alternative smaller plots were established therein. Thus, all islands smaller than 2 ha and those between 2 and 10 ha were sampled by trapping plots of only one and two pitfall arrays, respectively. Larger islands were sampled by as many as four trapping plots, according to their size categories: 10 to 50 ha, 50 to 200 ha, 200 to 500 ha and $>500$ ha, respectively; CF sites were sampled by either four $(n=3)$ or six trapping plots $(n=2$; for further details on sampling effort per site, see Table A.1).

We sampled a total 5447 trap-days across 71 trapping plots which were sampled twice during 16 consecutive days at each site, from April to November in 2014 and the same season in 2015, except for four $\mathrm{CF}$ sites $\left(\mathrm{CF}_{1}, \mathrm{CF}_{2}, \mathrm{CF}_{2 \text {-riparian }}\right.$ and $\left.\mathrm{CF}_{4}\right)$. Due to logistic restrictions, those CF four sites were only sampled during either the first (2014) or second (2015) field season (Table A.1). All traps were checked daily and four voucher specimens of each species were deposited at the herpetofaunal collection of the National Institute of Research of the Amazon (Instituto Nacional de Pesquisas da Amazônia - INPA), Manaus, Brazil. In addition, during the second field season we collected tissue samples for genetic analyses by carefully removing the tail tip of every individual. This further allowed us to distinguish individuals that had been previously captured. As observed during the second field season, recaptures corresponded to a small fraction of the total number of records $(<2 \%)$, with only three species being recaptured - Ameiva ameiva (recapture rate $=6.1 \%$ ), Arthrosaura reticulata $(0.8 \%)$ and Kentropyx spp. (2.7\%). For this reason, all individuals recorded during the first field season were assumed to have been captured only once. Furthermore, captures representing the genera Leposoma spp. (L. percarinatum and L. guianense), Norops spp. (N. planiceps and N. chrysolepis), and Kentropyx spp. (K. calcarata and K.

altamazonica) could not be identified to species level at all sampled sites. As congeners within those genera are ecologically very similar (Ávila-Pires, 1995), we hereafter refer to those taxa as 'species'. Capture and handling of all specimens in this study was approved by the appropriate Brazilian institutional biodiversity sampling and animal care committee (SISBIO license No. 39187-4).

\subsection{Patch and landscape spatial metrics}

Spatial metrics - including island area, shape, distance to CF and a proximity index were extracted from georeferenced shape files from the study area using a GIS (ArcMap 10.1; ESRI, 2012). Shape files had been previously obtained from high-resolution multispectral RapidEye imagery (5-m resolution with 5-band colour imagery; for further

190 details on image acquisition and processing, see Benchimol and Peres, 2015b). Island shape is defined as the ratio between island perimeter and its area, indicating the intensity of edge effects. As in Benchimol and Peres (2015b), the McGarigal, Cushman and Ene (2012) proximity index was modified by considering the total size of any land mass within the buffer, rather than excluding land areas outside the buffer connected to patches encompassed by the buffer. We used Generalized Linear Models (GLMs) to analyse the relationship between the number of species recorded in the islands and the proximity index considering each of the buffers $-250 \mathrm{~m}, 500 \mathrm{~m}$ and $1000 \mathrm{~m}-$ in separate models. We then ordered the models according to its Akaike Information 
Criteria (AIC; Burnham and Anderson, 2002). For further analyses, we retained the proximity index obtained with the $1000 \mathrm{~m}$-buffer $(\mathrm{AIC}=104.76)$, instead of the $500 \mathrm{~m}$ (106.73) or $250 \mathrm{~m}(110.82)$ buffers. Island area, shape and proximity index were $\log _{10^{-}}$ transformed prior to analysis. We further checked pairwise correlations between spatial metrics, excluding island shape from further models, because it was highly correlated with island area $(\mathrm{r}=-0.88)$. Whenever CF sites were included in the analysis, an area of $14660 \mathrm{ha}$ - equivalent to one order of magnitude larger than the largest surveyed island - was arbitrarily attributed to each of them.

\subsection{Species traits}

Traits hypothesized to be related to the ability of lizard species to persist within Balbina 210 archipelagic landscape were: (1) thermoregulation mode - heliophile and heliophobe; (2) type of habitat used - terra firme forest (i.e. typical Amazonian closed-canopy forest that is never seasonally inundated), clearings and forest edges, forest creeks and swamps; (4) body size, expressed as the maximum snout-vent length (SVL; i.e. from the tip of snout to cloaca); and (5) range of prey size (e.g. arthropods) within four ordinal

215 classes: 0 to $<20 \mathrm{~mm}, 20$ to $<60 \mathrm{~mm}, 60$ to $<140 \mathrm{~mm}$, and $>140 \mathrm{~mm}$ (Table 1 ). Species traits were obtained from Martins (1991) based on individual lizard species captured in the same landscape (both within islands and surrounding mainland forest), supplemented by additional information from a comprehensive review of the lizard fauna of the Brazilian Amazon (Ávila-Pires, 1995). Trait information was unavailable

220 within these sources for four species. Species traits for those species were obtained from specific literature, either regarding the same species (Prionodactylus oshaughnessyi: Vitt et al., 2003) or a congener, whenever information was not available for that species (Bachia panoplia: Ramos-Pallares et al., 2015; Amphisbaena fuliginosa: Bernardo-Silva et al., 2006; Ptycoglossus brevifrontalis: Anaya-Rojas et al., 2010).

\subsection{Data analysis}

We performed individual-based rarefaction curves to evaluate the representativeness of the sampling effort at each sampling site, except for islands smaller than 1 ha $(N=4)$ in which only one $(N=2)$ to two individuals $(N=2)$ were recorded. Nevertheless, we

230 assumed the sampling effort to be adequate therein due to its density of traps ( $\mathrm{min}-$ max: $0.67-1.25$ traps/ha), which was much higher than either in islands larger than 50 ha $(0.01-0.11$ traps/ha) or CF sites ( 0.001 traps/ha).

Species richness was extrapolated in the four CF sites sampled only once, due to the lower number of individuals recorded therein (mean \pm SD: $40.8 \pm 11.4$ individuals) in comparison to the CF site sampled in both field seasons ( 98 individuals). To do so, a bootstrap method was used to determine confidence intervals around Hill numbers, facilitating the comparison of multiple assemblages of extrapolated samples (Chao et al., 2014). Extrapolation of individual-based Hill numbers was performed considering the number of individuals recorded in $\mathrm{CF}_{3}$ and using the $\mathrm{R}$ codes provided by Chao et

240 al. (2014). Multivariate patterns of species composition were investigated using a Principal Coordinate Analysis (PCoA) ordination based on a Bray-Curtis similarity matrix including all 30 surveyed sites. Due to differential sampling effort per site, species abundances were previously standardized for each site. The $\mathrm{PCoA}_{1}$ scores were then used as a measure of species composition in subsequent analyses.

Considering the 25 islands surveyed, GLMs were used to examine the effects of patch and landscape metrics on species richness and composition. A candidate model set was constructed using all additive combinations of explanatory metrics, and models were ranked based on their AIC corrected for small sample sizes $\left(\mathrm{AIC}_{\mathrm{c}}\right.$ : Burnham and 
Anderson, 2002), using the 'MuMIn' R package (Bartoń, 2014). We did not repeat these modelling procedures including mainland CF sites because, when these sites were included, proximity was highly correlated with island area $(r=0.84)$. Since island area was the best predictor of species richness, we additionally examine species-area relationships (SARs) using both exponential and power models, as they perform well in explaining SARs (Matthews et al., 2015). Data fitting for each model was compared according to AIC values and the exponential model was observed to fit the data better $(\mathrm{AIC}=83.39)$ than the power model $(\mathrm{AIC}=91.04$; Table A.2).

Standardized species abundance and aggregated biomass estimates were further related to forest patch size for all 30 survey sites, distinguishing species functional groups based on their thermoregulation mode. To estimate aggregate biomass, the body mass of all individuals sampled per sampling site was summed, based on mean live weights per species obtained both in the field and from the literature (Table A.3). Whenever this information was unavailable, body mass was assumed to be equivalent to another species of the same genus (three species) or based on a species with comparable maximum SVL (two species). To evaluate this relationship, GLMs were separately

265 applied for heliophile and heliophobe species, considering species abundance $\left(\log _{10} \mathrm{X}+\right.$ 1 ) and biomass $\left(\log _{10} \mathrm{x}\right)$ as response variables and forest area $\left(\log _{10} \mathrm{x}\right)$ as the explanatory variable. Models were fitted both including and excluding the quadratic term of 'forest area', and its AIC was compared (Burnham and Anderson, 2002). Except for the GLM explaining the abundance of heliophobe species, all other GLMs included the quadratic term of 'forest area' (Table A.4).

Considering each of the 30 survey sites and species according to their thermoregulation mode, species rank-abundance distribution (RAD) curves (on a $\ln (\mathrm{x})$ scale) and Pielou's community evenness estimates (J') were additionally examined using the 'vegan' R package (Oksanen et al., 2007). This measure of evenness is the most widely used in ecology, ranges from 0.0 to 1.0 , and represents changes in abundance distributions from most to least uneven (He and Legendre, 2002).

To assess how species with different traits respond to gradients of spatial metrics, an RLQ analysis was performed using the R package 'ade4' (Dray and Dufour, 2007). This multivariate analysis provides ordination scores to summarize the joint 280 structure among three tables - environmental variables (matrix R), species abundances (matrix L), and species traits (matrix Q) - by arranging (1) sites according to the species traits they contain, and (2) species according to environmental variables describing the sites in which they occur (Dray et al., 2003, 2014). The total amount of variation explained by RLQ analysis is limited to the variance explained by the separate

285 ordinations or each matrix. For all 30 survey sites, standardized species abundance data were ordered using Correspondence Analysis (CA; Tenenhaus and Young, 1985); spatial metrics using Principal Components Analysis (PCA; Tenenhaus and Young, 1985), and species traits using Hill-Smith PCA (Hill and Smith, 1976), due to the inclusion of both continuous and categorical variables. All data analyses were performed in R (R Development Core Team, 2015).

\section{Results}

Excluding recaptures, a total of 1123 lizards from 30 sampled sites were recorded across 17 species or morphospecies, 17 genera and 6 families. The number of species per site ranged from as few as one to 11 across all 25 islands (mean \pm SD: $5.16 \pm 3.22$ species), and from eight to 11 across the five CF sites (9.25 \pm 1.36 species). Most species recorded on islands were also present in CF sites, except for two rare species, 
Bachia panoplia and Ptycoglossus brevifrontalis, which were recorded only once and twice, respectively, throughout the sampling. The teiid lizard Kentropyx spp. was by far the most abundant $(N=431)$ and ubiquitous species, recorded at 27 of the 30 sites. Two riparian species, Uranoscodon superciliosus $(N=1)$ and Neusticurus bicarinatus $(N=$ $2)$, were exclusively recorded at the riparian trapping plot placed along perennial stream banks in $\mathrm{CF}_{2}$. Overall, rarefaction curves indicated that sampling effort was representative in most islands and in one of the CF sites sampled in both field seasons (Fig. A.1). Although rarefaction curves did not provide clear evidence for sampling effort representativeness for some islands ranging from 1 to 50 ha (Fig. A.1a), trap density therein was higher ( $\min -\max : 0.09-0.91 \mathrm{traps} / \mathrm{ha})$ than in larger islands $(0.01$ - $0.1 \mathrm{traps} / \mathrm{ha})$ and CF ( $0.001 \mathrm{traps} / \mathrm{ha}$; Table A.1).

310 Considering all patch and landscape metrics, island area was by far the best predictor of lizard species richness $(\mathrm{S})$ within the Balbina archipelago $\left(\beta_{\text {area }}=3.100, P<\right.$ 0.000 ; Tables 2 and A.5), explaining $87.3 \%$ of the overall variation in $\mathrm{S}$. The number of species persisting within the three smallest surveyed islands ( $\leqslant 2 \mathrm{ha})$ was less than a third of the species richness typically observed in islands larger than 100 ha and CF sites ( $\geqslant 8$ species, Fig. 2). Only islands larger than 100 ha, which account for only $\sim 5 \%$ of the entire archipelago, still harboured nearly complete lizard assemblages.

Likewise, considering all spatial metrics examined here (Table 2), lizard species composition within islands was also best explained by island area $\left(\beta_{\text {area }}=-0.202, P<\right.$ $0.000, \mathrm{R}^{2}=0.58$; Table A.5). A PCoA ordination plot that included mainland CF sites

320 indicates that lizard species composition was more similar between sites sharing a similar forest area and this appears to be mediated by the abundance ratio between species functional groups with contrasting modes of thermoregulation (Fig. 3a). The proportion of heliophobe individuals declined as insular forest area decreased, so that smaller islands were largely occupied by heliophile species (Fig. 3b). This was reinforced when species with different thermoregulatory behavioural patterns were in turn considered separately. The abundance of heliophile species presented a concave relationship with forest area increase, decreasing from midsized islands towards $\mathrm{CF}$ sites $\left(\beta_{\text {area }}=0.789 ; P<0.000 ; \beta_{\text {area }}{ }^{2}=-0.172 ; P<0.000\right)$. Conversely, the abundance of heliophobe species presented a linear relationship (Fig. 4a), increasing continuously 330 in increasingly larger forest sites $\left(\beta_{\text {area }}=0.017 ; P=0.010\right.$; Table A.6). Moreover, the aggregate biomass also presents a concave relationship with forest area for both heliophile $\left(\beta_{\text {area }}=1.351 ; P<0.000 ; \beta_{\text {area }}{ }^{2}=-0.286 ; P<0.000\right)$ and heliophobe species $\left(\beta_{\text {area }}=1.110 ; P<0.000 ; \beta_{\text {area }}{ }^{2}=-0.192 ; P=0.003\right.$; Table A.6). Still, the aggregate biomass of heliophile lizards tended to be higher than that of heliophobe species at intermediate to large island sizes, while aggregate biomass of both species groups at $\mathrm{CF}$ sites converged (Fig. 4b).

The turnover in species abundance and biomass along the gradient of insular forest area, taking into account species thermoregulation modes, is additionally illustrated by the corresponding RAD curves (Fig. 5) and community evenness of each 340 site, with $66.5 \%$ of the variation in equitability ( $\mathrm{J}$ ') values explained by island size. At islands $\leqslant 10$ ha, lizard assemblages were largely represented by heliophile species, corresponding to $70.3 \pm 14.6 \%$ of all individuals. Yet, J' values were higher therein, ranging from 0.82 to 1.00 (mean $\pm \mathrm{SE}=0.87 \pm 0.05, N=9$ ), in comparison to islands $\geqslant 100$ ha and mainland CF sites $\left(\mathrm{J}^{\prime}=0.63 \pm 0.02, N=13\right.$, range $\left.=0.53-0.73\right)$. At those larger sites, lizard assemblages were instead dominated by heliophobe species, which accounted for $56.3 \pm 5.9 \%$ of all individuals. In addition, the area below the curve, which approximately represents the overall community size at each site, was greater in 
increasingly larger forest islands (Fig. 5), reinforcing the overall pattern of highly defaunated small islands.

350 Lizard species trait-environment relationships at the Balbina archipelago were informatively illustrated by the RQL analysis, the first axis of which explained $94.6 \%$ of total variance between species traits and spatial metrics of all survey sites (Table A.7). Heliophobe species associated with moist leaf-litter foraging substrates of the heavily shaded understorey of terra firme forest, water-logged soils, and along forest streams were positively correlated with large forest areas under low levels of isolation from other land masses. In contrast, species characterized by larger body size (longer SVL), sun-seeking thermoregulation mode associated with forest clearings and edges, and generalist food habits in terms of prey body size were clearly positively correlated with small islands exposed to more intensive edge effects and located farther from the mainland (Fig. 6).

\section{Discussion}

Permanent damming of major waterways in lowland Amazonia, in addition to reducing the productivity of aquatic habitats (Palmeirim et al., 2014; Castello and Macedo, 2015), creates highly fragmented archipelagic landscapes consisting of hundreds or thousands of land-bridge islands. Yet official energy development policy in Brazil and other Amazonian countries endorses the construction of as many as 246 new hydroelectric dams (Lees et al., 2016). In the Balbina Hydroelectric Reservoir, roughly $95 \%$ of all $>3$

370500 islands, which have been isolated for over 28 years, are smaller than 100 ha, and these islands can at best sustain moderately to highly depleted diurnal lizard assemblages. In a previous study 20 years after isolation, which sampled only 20 islands within a narrower size spectrum (largest island $=220 \mathrm{ha}$ ), the number of lizard species retained in small islands was already very reduced (Bittencourt, 2008). In contrast, species richness in islands $>100$ ha was comparable to that of mainland sites (Bittencourt, 2008). Assemblages of large terrestrial and arboreal vertebrate species in islands larger than 475 ha, which account for only $0.7 \%$ of all islands, were also comparable to those in mainland sites (Benchimol and Peres, 2015b). Moreover, we detected a similar number of species compared to two previous studies in the same 380 archipelagic landscape that used visual encounter surveys, including the forest litter (21 species: Martins, 1991; 16 species: Bittencourt, 2008). However, although we recorded some strictly arboreal species, such as Norops sp., Plica umbra and Uranoscodon superciliosus, their detection rates were almost certainly hindered by the use of pitfall traps. Extrapolating these results to other lizard assemblages that include arboreal species would therefore require caution.

\subsection{Applied island biogeography}

Island size was by far the best predictor of lizard species richness at the Balbina archipelago 28 years post-isolation, generating one of the strongest species-area

390 relationships ever documented for any vertebrate taxon in true archipelagos (Matthews et al., 2015). Species ability to persist in forest fragments is affected by the amount of patch-scale forest area (MacArthur and Wilson, 1967), which constrains population sizes (Connor et al., 2000). At Balbina, small islands are more likely to experience forest habitat degradation, including severe edge effects (Benchimol and Peres, 2015a), so the availability and spectrum of both trophic and structural resources are expected to be much lower in those islands. The strong dependence of Amazonian lizard species on local microhabitat features (Garda et al., 2013) may further contribute to the robust SAR 
reported here. This is consistent with several other neotropical studies that have pointed out the importance of forest area in predicting the diversity of lizard faunas in fragmented landscapes (e.g. Bell and Donnelly, 2006; Cabrera-Guzmán and Reynoso, 2012; Almeida-Gomes and Rocha, 2014). In the same set of Balbina islands, island size also best predicted the species richness of birds (Aurélio-Silva et al., 2016) and large terrestrial and arboreal vertebrates (Benchimol and Peres, 2015b).

In contrast to expectations derived from the Equilibrium Theory of Island Biogeography (MacArthur and Wilson, 1967), isolation failed to explain patterns of lizard species richness in Balbina archipelagic landscape. This was also the case for birds (Aurélio-Silva et al., 2016) and mammals (Benchimol and Peres, 2015b) inhabiting Balbina islands, as well as for lizard assemblages in other fragmented tropical forests (Bell and Donnelly, 2006; Almeida-Gomes and Rocha, 2014). Such lack

410 of isolation effects on the number of lizard species may result from the effective isolation provided by the inhospitable aquatic matrix even for islands near the mainland, at least for small-bodied species (Schoener and Schoener, 1984). Indeed, under the power model the SAR observed here was further characterized by a steep positive slope and a relatively high $Z$-value, which are consistently related to low matrix permeability and immigration rates (Watling and Donnelly, 2006). This further suggests that Balbina's lizards have experienced overall higher area-related local extinction rates and/or lower recolonization rates than equivalent habitat fragments embedded within either cattle pastures or fast-growing tree plantations across lowland tropical and subtropical biomes (see summary of studies in Table 3 ). Such findings are not surprising

420 given the typically low dispersal capacity of lizards (Garda et al., 2013), and the aggravating circumstances of enormous contrasts between insular forest fragments in terrestrial landscapes and those surrounded by a wide open-water matrix. Observed declines in lizard species richness in Balbina islands was similar to that shown for an eastern Amazonian archipelagic landscape created by the Tucuruí Dam (Lima, 2008). Yet even steeper declines in lizard species richness could be observed in insular faunas of China's Thousand Island Lake (Wang et al., 2009). Moreover, the similarly steep SAR slopes of both land-bridge islands surveyed here and oceanic archipelagos are consistent with the relative balance between species immigration and extinction (MacArthur and Wilson, 1967; Table 3), further stressing the effective isolation 430 provided by an inhospitable aquatic matrix.

Given the likely rarity of matrix movements in the Balbina archipelago, we were able to detect the effects of both habitat loss and fragmentation 'per se', which are expected to be divorced from confounding matrix effects. Our findings further underline comparisons with other continental studies, which are typically characterized by

435 structurally complex terrestrial landscapes (e.g. Lion et al., 2016; Russildi et al., 2016), calling for an improved understanding of matrix effects (Cosson et al., 1999), particularly when matrix quality fails to be considered (e.g. Cabrera-Guzmán and Reynoso, 2012).

\section{$440 \quad 4.2$ Heliophile vs heliophobe species}

Over and above this species-area pattern, small islands are typically more edgedominated and more likely to be disturbed by wind-throws and wildfires (Benchimol and Peres 2015a), thereby compounding gap propagation through area effects and shifting the functional composition of lizard assemblages. This was evidenced by the strong relationship between island size and lizard species composition which can be described by the abundance ratio between heliophile and heliophobe species, and further illustrated by the RAD curves (Fig. 5). Strong convective windstorms at Balbina islands 
lead to significantly higher rates of tree falls near forest edges, which further impact vegetation structure (Benchimol and Peres, 2015a), elevating both heat penetration and desiccation in the understorey (Scheffers et al., 2016). Such changes alter habitat quality and microclimate for lizards, whose basic physiology, and consequently their ability to capture and metabolize food, escape predators and reproduce, is temperature dependent (Huey and Stevenson, 1979). Indeed, most neotropical reptile species respond to edge effects in fragmented landscapes, either increasing or decreasing their abundances depending on their metabolic ecology (Schneider-Maunoury et al., 2016).

Heliophobe species have lower body temperatures (on average $27.7^{\circ} \mathrm{C}$ ) but maintain those temperatures in shaded habitats (Vitt et al., 1998). Forest dependent species were apparently extirpated from most smaller and medium sized islands $(<100$ ha), probably due to intense edge effects therein, even within core areas of island 460 interior (AFP and CAP, unpubl. data). This is unlikely a sampling artefact as pitfall-trap density in our small islands $(<10 \mathrm{ha})$ were on average 34 -fold higher than those in islands $>100$ ha and mainland continuous forest sites. Conversely, heliophobe species apparently thrived in larger islands and mainland CF sites, in terms of both species abundance and aggregate biomass. As shown in RAD curves (Fig. 5), heliophobe species dominated lizard assemblages in larger islands and mainland CF sites. In an exhaustive survey on lizard assemblages in continuous terra firme forests experiencing little or no human disturbance in an entirely terrestrial landscape $\sim 125 \mathrm{~km}$ from Balbina, Pinto (2006) also reported heliophobe species to be more abundant ( $70 \%$ of all individuals recorded) compared to heliophiles. Heliophile species have higher body 470 temperatures (on average $36.1^{\circ} \mathrm{C}$ ) and use understorey sunflecks to regulate their core body temperature (Vitt et al., 1998). The typical dominance of heliophile species at Balbina islands smaller than 100 ha is likely due to their higher day-time temperatures and more numerous forest gaps exposed to direct sunlight. Although we did not observe significant changes in the overall patterns of heliophile species abundance and biomass along the island size gradient, the abundance of three heliophile species that were also represented at Balbina - Kentropyx calcarata, Ameiva ameiva and Mabuya nigropunctata - increased within selectively logged forests with elevated canopy gap density in a neighbouring landscape $90 \mathrm{~km}$ north of Manaus (Lima et al., 2001).

Throughout the forest island size gradient, shifts in functional composition of

480 lizard assemblages covaried with changes in community evenness. Lizard species abundances were less evenly distributed at large islands ( $>100 \mathrm{ha})$ and mainland CF sites compared to small islands ( $\leq 10 \mathrm{ha}$ ). This was unexpected, as greater species dominance in a given area usually lead to declining species richness via competitive exclusion (He and Legendre, 2002; but see Soininen et al., 2012). However, J' values are weighted by the local species richness (He and Legendre, 2002), which declined with island size. Thus, J' values derived here cannot be considered representative of the equitability of abundances 'per se', but are instead related to local community size. Higher J' values in small islands may be a function of the loss of forest dependent/rare species (Sánchez de Jesús et al., 2016).

\subsection{Other species persistence-related traits}

Residual lizard assemblages within small, edge-dominated islands - that were typically more isolated from other islands and mainland forest areas - were further characterized by a size structure skewed towards larger-bodied species associated with forest clearings and forest edges, and generalist food habits. Body size is also positively correlated with lizard ability to traverse the aquatic matrix (Schoener and Schoener, 1984). Likewise, feeding on a greater spectrum of prey sizes may be an advantage in 
persisting in more degraded islands, where a narrow range of prey items may be available (Connor et al., 2000). Large body size and generalist food habits largely match the heliophile members of the family Teiidae, which are also fast moving and active foragers (Sartorius et al., 1999), such as the highly abundant Kentropyx spp. and $A$. ameiva. Because generalist heliophile lizards are also more adept at interference competition with other faunivores in smaller, edge-degraded islands (Frishkoff et al., 2015), their dominance therein may further exacerbate cascading effects on terrestrial species, thereby triggering an added mechanism of altered community structure (Vitt et al., 1998; Sartorius et al., 1999). The prevalence of teiid species has also been observed in other Amazonian lizard communities in areas of anthropogenic treefalls gaps (Vitt et al., 1998; Lima et al., 2001; Gardner et al., 2007b) and forest edges (Sartorius et al., 1999; Silva et al., 2014).

510 On the flip side of the degradation gradient, lizard communities in larger and less isolated forest islands included many heliophobe species typical of undisturbed terra firme forest, forest streams and water-logged soils, including several riparian species. Indeed, riparian habitats were virtually extirpated from forest islands, as damming inundated all lowland forest areas. This almost certainly led to the extinction of forest

515 habitat specialists, such as the two riparian species - U. superciliosus and $N$. bicarinatus - recorded only in the continuous forest along a perennial stream $\left(\mathrm{CF}_{2-}\right.$ riparian). Likewise, the extirpation of forest specialists was also noted for amphibians in a man-made archipelagic landscape eastern Amazon (Lima et al., 2015) and in a cerrado site in the Brazilian scrub savanna (Brandão and Araújo, 2008).

\subsection{Conservation implications}

In contrast with the relatively higher conservation value of forest fragments embedded within terrestrial matrices (e.g. Silva, 2005; Lion et al., 2016), small land-bridge islands within the Balbina reservoir were highly defaunated not just of lizards but also of a range of other vertebrate taxa including birds (Aurélio-Silva et al., 2016), and mammals (Benchimol and Venticinque, 2014; Benchimol and Peres, 2015b). Moreover, lizard species persisting in small islands typically correspond to a depauperate set of warmadapted habitat generalists. This functional impoverishment is thought to profoundly affect ecosystem functioning in small habitat remnants (Miller et al., 2015).

530 Conservation and management efforts must therefore take into account the functional composition of residual assemblages, and whenever possible, be targeted to habitat specialists, which in the case of tropical forest lizards include primarily small-bodied heliophobes with a restricted prey size spectrum. Ensuring the persistence of those specialists will require maintaining a heterogeneous mosaic of forest microhabitats

535 (Garda et al., 2013), including riparian zones in lowland forest.

Terrestrial and freshwater ecosystems across the lowland Amazonia are facing escalating pressures from the ambitious hydropower sector driven by the burgeoning Brazilian economy, resulting in severe habitat fragmentation and degradation (Castello and Macedo, 2015; Lees et al., 2016). Yet, mitigating the impact or revoking new

540 hydroelectric dams would prevent the creation of large numbers of small land-bridge islands and avoid additional biodiversity losses. Whenever a mega-dam is entirely inevitable, hydraulic engineers could adjust hydropower outputs according to a lower maximum reservoir water level to augment land-mass coalescence, thereby boosting the number of large islands. Caution must still be exercised even within larger islands that

545 can support more complete communities, since these insular systems often fail to sustain full complements of flora and fauna in the long term (Jones et al., 2016). Careful basin-wide planning is therefore critical to avoid wholesale species extinctions and 
losses in forest ecosystem services. Finally, biodiversity loss should be weighed alongside other environmental costs in future assessments of hydropower development in the world's mega-diverse tropical rivers.

\section{Acknowledgements}

We are grateful to Rafael, Amanda, França, Wilson, Mara, Evanir, Rebecca, Daianny, Bruna, Fred, Renato, Ricardo, Joelson, Filipe and Electra for assistance during fieldwork; the Reserva Biológica do Uatumã and its managers for logistical support; R. de Fraga, A. Silva for critical help with species identification; F. Werneck for logistical support; M. Benchimol and D. Stork for access to Balbina imagery; F. Farneda for assistance with the statistical analysis. This study was funded by the Amazon Region

560 Protected Areas Program (ARPA), Amazonas Distribuidora de Energia S.A, and Associação Comunidade Waimiri Atroari; the Rufford Foundation (grant number 13675-1) and Idea Wild; and a NERC grant (NE/J01401X/1) awarded to CAP. AFP was funded by the Programa de Pós-Graduação em Ecologia, Universidade Federal do Rio de Janeiro, and a CAPES scholarship from the Brazilian Ministry of Education. MVV

565 was funded by Fundação de Amparo à Pesquisa do Estado do Rio de Janeiro (FAPERJ) and Conselho Nacional de Desenvolvimento Científico e Tecnológico (CNPq).

\section{Literature Cited}

570 Almeida-Gomes, M., Rocha, C.F.D. 2014. Diversity and distribution of lizards in fragmented Atlantic Forest landscape in Southeastern Brazil. Journal of Herpetology 48, 423-429.

Anaya-Rojas, J.M., Serrano-Cardozo, V.H., Ramírez-Pinilla, M.P. 2010. Diet, microhabitat use, and thermal preferences of Ptychoglossus bicolor (Squamata: Gymnophthalmidae) in an organic coffee shade plantation in Colombia. Papéis Avulsos de Zoologia (São Paulo) 50, 159-166.

Aurélio-Silva, M., Anciães, M., Henriques, L.M.P., Benchimol, M., Peres, C.A. 2016. Patterns of local extinction in an Amazonian archipelagic avifauna following 25 years of insularization. Biological Conservation 199, 101-109.

580 Ávila-Pires, T.C.S. 1995. Lizards of Brazilian Amazonia (Reptilia: Squamata). Zoologische verhandelingen 299, 1-706.

Bartoń, K. 2014. MuMIn: multi-model inference. R package version 1.10.5.

Bell, K.E., Donnelly, M.A. 2006. Influence of forest fragmentation on community structure of frogs and lizards in northeastern Costa Rica. Conservation Biology

$585 \quad 20,1750-1760$.

Benchimol, M., Peres, C.A. 2015a. Edge-mediated compositional and functional decay of tree assemblages in Amazonian forest islands after 26 years of isolation. Journal of Ecology 103, 408-420.

Benchimol, M., Peres, C.A. 2015b. Widespread forest vertebrate extinctions induced by

590 a mega hydroelectric dam in lowland Amazonia. PloS one 10, e0129818.

Benchimol, M., Venticinque, E.M. 2014. Responses of Primates to Landscape Change in Amazonian Land-bridge islands - a Multi-scale Analysis. Biotropica 46, 470 478.

Bernardo-Silva, J.S., Von-Mühlen, E.M., Di-Bernardo, M., Ketterl, J. 2006. Feeding ecology in the small neotropical amphisbaenid Amphisbaena munoai (Amphisbaenidae) in southern Brazil. Iheringia (Série Zoologia) 96, 487-489. 
Bittencourt, S. 2008. A insularização como agente de fragmentação florestal em comunidades de lagartos na Amazônia Central. Master Thesis. National Institute of Research of the Amazon and Federal University of the Amazonas State, Brazil.

Böhm, M., Collen, B., Baillie, J.E., Bowles, P., Chanson, J., Cox, N., et al. 2013. The conservation status of the world's reptiles. Biological Conservation 157, 372385.

Brandão, R.A., Araújo, A.F. 2008. Changes in anuran species richness and abundance resulting from hydroelectric dam flooding in Central Brazil. Biotropica 40, 263 266.

Burnham, K.P., Anderson, D.R. 2002. Model selection and multi-model inference: a practical information-theoretic approach, Springer-Verlag, London.

Cabrera-Guzmán, E., Reynoso, V.H. 2012. Amphibian and reptile communities of rainforest fragments: minimum patch size to support high richness and abundance. Biodiversity and Conservation 21, 3243-3265.

Carvajal-Cogollo, J.E., Urbina-Cardona, N. 2008. Patrones de diversidad y composición de reptiles en fragmentos de bosque seco tropical en Córdoba, Colombia. Tropical Conservation Science 1, 397-416.

Carvajal-Cogollo, J.E., Urbina-Cardona, N. 2015. Ecological grouping and edge effects in tropical dry forest: reptile-microenvironment relationships. Biodiversity and Conservation 24, 1109-1130.

Case, T.J. 1975. Species numbers, density compensation, and colonizing ability of lizards on islands in the Gulf of California. Ecology 56, 3-18.

Castello, L., Macedo, M.N. 2015. Large-scale degradation of Amazonian freshwater ecosystems. Global Change Biology. doi: 10.1111/gcb.13173.

Castello, L., Macedo, M.N. 2015. Large-scale degradation of Amazonian freshwater ecosystems. Global change biology 22, 990-1007.

Chao, A., Gotelli, N.J., Hsieh, T.C., Sander, E.L., Ma, K.H., Colwell, R.K., Ellison, A.M. 2014. Rarefaction and extrapolation with Hill numbers: a framework for sampling and estimation in species diversity studies. Ecological Monographs 84, 45-67.

Connor, E.F., Courtney, A.C., Yoder, J.M. 2000. Individuals-area relationships: the relationship between animal population density and area. Ecology 81, 734-748.

Cosson, J.F., Ringuet, S., Claessens, O., De Massary, J.C., Dalecky, A., Villiers, J.F., Granjon, L., Pons, J.M. 1999. Ecological changes in recent land-bridge islands in French Guiana, with emphasis on vertebrate communities. Biological Conservation 91, 213-222.

Dray, S., Chessel, D., Thioulouse, J. 2003. Co-inertia analysis and the linking of ecological data tables. Ecology 84, 3078-3089.

Dray, S., Choler, P., Dolédec, S., Peres-Neto, P.R., Thuiller, W., Pavoine, S., ter Braak, C.J. 2014. Combining the fourth-corner and the RLQ methods for assessing trait responses to environmental variation. Ecology 95, 14-21.

Dray, S., Dufour, A.B. 2007. The ade4 package: implementing the duality diagram for ecologists. Journal of Statistical Software 22, 1-20.

ESRI. 2012. ArcMap 10.1. Environmental Systems Research Institute Inc., Redlands, CA, USA.

Fearnside, P.M., Pueyo, S. 2012. Greenhouse-gas emissions from tropical dams. Nature Climate Change 2, 382-384. 
Frishkoff, L.O., Hadly, E.A., Daily, G.C. 2015. Thermal niche predicts tolerance to habitat conversion in tropical amphibians and reptiles. Global Change Biology 21, 3901-3916.

FUNCATE/INPE/ANEEL. 2000. Mapeamento por satélite das áreas inundadas por reservatórios de hidrelétricas brasileiras. Unpublished Report. Convênio FUNCATE/INPE/ANEEL, São Paulo.

Garda, A.A., Wiederhecker, H.C., Gainsbury, A.M., Costa, G.C., Pyron, R.A., Calazans Vieira, G.H., Werneck, F., Colli, G.R. 2013. Microhabitat Variation Explains Local-scale Distribution of Terrestrial Amazonian Lizards in Rondônia, Western Brazil. Biotropica, 45, 245-252.

655 Gardner, T. A., Ribeiro-Júnior, M.A., Barlow, J.O.S., Ávila-Pires, T.C.S., Hoogmoed, M.S., Peres, C.A. 2007b. The value of primary, secondary, and plantation forests for a Neotropical herpetofauna. Conservation Biology 21, 775-787.

Gardner, T.A., Barlow, J., Peres, C.A. 2007a. Paradox, presumption and pitfalls in conservation biology: The importance of habitat change for amphibians and reptiles. Biological Conservation 138, 166-179.

He, F., Legendre, P. 2002. Species diversity patterns derived from species-area models. Ecology 83, 1185-1198.

Hill, M.O., Smith, A.J.E. 1976. Principal component analysis of taxonomic data with multi-state discrete characters. Taxon 25, 249-255.

665 Huey, R.B. 1974. Behavioral thermoregulation in lizards: importance of associated costs. Science 184, 1001-1003.

Hutchinson, G.E. 1957. Concluding remarks. Cold Spring Harbor Symposium on Quantitative Biology 22, 415-427.

IBAMA. 1997. Plano de Manejo Fase I: Reserva Biológica do Uatumã. Eletronorte/IBAMA. Brasília/DF/Brazil. Available at the following web site: http://www.icmbio.gov.br.

IUCN, 2015. The IUCN Red List of Threatened Species. Version 2015-4. Available at the following web site: http://www.iucnredlist.org.

Jones, I.L., Bunnefeld, N., Jump, A.S., Peres, C.A., Dent, D.H. 2016. Extinction debt on reservoir land-bridge islands. Biological Conservation 199, 75-83.

Laurance, W.F., Ferreira, L.V., Rankin-de Merona, J.M., Laurance, S.G. 1998. Rain forest fragmentation and the dynamics of Amazonian tree communities. Ecology 79, 2032-2040.

Lees, A.C., Peres, C.A., Fearnside, P.M., Schneider, M., Zuanon, J.A. 2016. Hydropower and the future of Amazonian biodiversity. Biodiversity and Conservation 25, 451-466.

Lima, A.P., Suárez, F.I., Higuchi, N. 2001. The effects of selective logging on the lizards Kentropyx calcarata, Ameiva ameiva and Mabuya nigropunctata. Amphibia-Reptilia 22, 209-216.

685 Lima, C.J. 2008. Efeito da fragmentação e isolamento da paisagem na riqueza e composição de espécies de lagartos no reservatório de Tucuruí, Pará. MSc thesis. Federal University of Pará, Belém, Brazil.

Lima, J.R., Galatti, U., Lima, C.J., Fáveri, S.B., Vasconcelos, H.L., Neckel-Oliveira, S. 2015. Amphibians on Amazonian land-bridge islands are affected more by area than isolation. Biotropica 47, 369-376.

Lion, M.B., Garda, A.A., Santana, D.J., Fonseca, C.R. 2016. The conservation value of small fragments for Atlantic Forest reptiles. Biotropica 0, 1-11.

MacArthur R.H., Wilson E.O. 1967. The Theory of Island Biogeography. Princeton University Press Princeton, New Jersey. 
Martins, M. 1991. The lizards of Balbina, Central Amazonia, Brazil: a qualitative analysis of resource utilization. Studies on Neotropical Fauna and Environment 26, 179-190.

Matthews, T.J., Guilhaumon, F., Triantis, K.A., Borregaard, M.K., Whittaker, R.J. 2015. On the form of species-area relationships in habitat islands and true islands. Global Ecology and Biogeography, doi: 10.1111/geb.12269.

McGarigal, K., Cushman, S.A., Ene E. 2012. FRAGSTATS v4: Spatial Pattern Analysis Program for Categorical and Continuous Maps. Computer software program produced by the authors at the University of Massachusetts, Amherst. Available at the following web site: http://www.umass.edu/landeco/research/fragstats/fragstats.html

Miller, J.E., Damschen, E.I., Harrison, S.P., Grace, J.B. 2015. Landscape structure affects specialists but not generalists in naturally fragmented grasslands. Ecology 96, 3323-3331.

Oksanen, J., Kindt, R., Legendre, P., O’Hara, B., Stevens, M.H.H., Oksanen, M.J., Suggests, M.A.S.S. 2007. Vegan: the community ecology package. R package version 2.4-2.

Palmeirim, A.F., Peres, C.A., Rosas, F.C. 2014. Giant otter population responses to habitat expansion and degradation induced by a mega hydroelectric dam. Biological Conservation 174, 30-38.

715 Perry, G., Rodda, G., Fritts, T., Sharp, T. 1998. The lizard fauna of Guam's fringing islets: island biogeography, phylogenetic history, and conservation implications. Global Ecology and Biogeography 7, 353-365.

Pinto, M.G.M. 2006. Diversidade beta, métodos de amostragem e influência de fatores ambientais sobre uma comunidade de lagartos na Amazônia Central. PhD Thesis. National Institute of Research of the Amazon and Federal University of the Amazonas State, Brazil.

R Development Core Team. 2015. R: A language and environment for statistical computing. R Foundation for Statistical Computing, Vienna, Austria. ISBN 3900051-07-0, URL < http://www.R-project.org/>.

Ramos-Pallares, E., Anaya-Rojas, J.M., Serrano-Cardozo, V.H., Ramírez-Pinilla, M.P. 2015. Feeding and Reproductive Ecology of Bachia bicolor (Squamata: Gymnophthalmidae) in Urban Ecosystems from Colombia. Journal of Herpetology 49, 108-117.

Russildi, G., Arroyo-Rodríguez, V., Hernández-Ordóñez, O., Pineda, E., Reynoso, V.H. 2016. Species-and community-level responses to habitat spatial changes in fragmented rainforests: assessing compensatory dynamics in amphibians and reptiles. Biodiversity and Conservation 25, 375-392.

Sánchez-de-Jesús, H.A., Arroyo-Rodríguez, V., Andresen, E., Escobar, F. 2016. Forest loss and matrix composition are the major drivers shaping dung beetle assemblages in a fragmented rainforest. Landscape Ecology 31, 843-854.

Sartorius, S.S., Vitt, L.J., Colli, G.R. 1999. Use of naturally and anthropogenically disturbed habitats in Amazonian rainforest by the teiid lizard Ameiva ameiva. Biological Conservation 90, 91-101.

Scheffers, B.R., Edwards, D.P., Macdonald, S.L., Senior, R.A., Andriamahohatra, L.R., Roslan, N., Andrew M., Rogers, Haugaasen, T., Wright, P., Williams, S.E. 2016. Extreme thermal heterogeneity in structurally complex tropical rain forests. Biotropica 48, 35-44.

Schneider-Maunoury, L., Lefebvre, V., Ewers, R.M., Medina-Rangel, G.F., Peres, C.A., Somarriba, E., Urbina-Cardona, N., Pfeifer, M. 2016. Abundance signals of 
amphibians and reptiles indicate strong edge effects in Neotropical fragmented forest landscapes. Biological Conservation 200, 207-215.

Schoener, A., Schoener, T.W. 1984. Experiments on dispersal: short-term floatation of insular anoles, with a review of similar abilities in other terrestrial animals. Oecologia 63, 289-294.

750 Silva, D.J. 2005. Efeitos da fragmentação sobre a comunidade de lagarto em áreas de floresta estacional semidecidual submontana no Sudoeste de Mato Grosso, Brasil. PhD Thesis. National Institute of Research of the Amazon and Federal University of the Amazonas State, Brazil.

Silva, D.J., Santos-Filho, M., Canale, G.R. 2014. The importance of remnant native vegetation of Amazonian submontane forest for the conservation of lizards. Brazilian Journal of Biology 74, 523-528.

Soininen, J., Passy, S., Hillebrand, H. 2012. The relationship between species richness and evenness: a meta-analysis of studies across aquatic ecosystems. Oecologia 169, 803-809.

Tenenhaus, M., Young, F.W. 1985. An analysis and synthesis of multiple correspondence analysis, optimal scaling, dual scaling, homogeneity analysis and other methods for quantifying categorical multivariate data. Psychometrika $50,91-119$.

Todd, B.D., Willson, J.D., Gibbons, J.W. 2010. The global status of reptiles and causes of their decline. Ecotoxicology of amphibians and reptiles, pp. 47-67, New York.

Vitt, L.J., Ávila-Pires, T.C.S., Caldwell, J.P., Oliveira, V.R. 1998. The impact of individual tree harvesting on thermal environments of lizards in Amazonian rain forest. Conservation Biology 12, 654-664.

Vitt, L.J., Ávila-Pires, T.C.S., Zani, P.A., Espósito, M. C., Sartorius, S.S. 2003. Life at the interface: ecology of Prionodactylus oshaughnessyi in the western Amazon and comparisons with $P$. argulus and P. eigenmanni. Canadian Journal of Zoology 81, 302-312.

Vitt, L.J., Zani, P.A., Espósito, M.C. 1999. Historical ecology of Amazonian lizards: implications for community ecology. Oikos 87, 286-294.

Wang, Y., Zhang, J., Feeley, K.J., Jiang, P., Ding, P. 2009. Life-history traits associated with fragmentation vulnerability of lizards in the Thousand Island Lake, China. Animal Conservation 12, 329-337.

Watling, J.I., Donnelly, M.A. 2006. Fragments as islands: a synthesis of faunal responses to habitat patchiness. Conservation Biology 20, 1016-1025.

Watling, J.I., Donnelly, M.A. 2008. Species richness and composition of amphibians and reptiles in a fragmented forest landscape in northeastern Bolivia. Basic and Applied Ecology 9, 523-532.

Winemiller, K. O., McIntyre, P.B., Castello, L., Fluet-Chouinard, E., Giarrizzo, T., Nam, S., Baird, I.G., Darwall, W., Lujan, N.K., Harrison, I., Stiassny, M.L.J., Silvano, R.A.M., Fitzgerald, D.B., Pelicice, F.M., Agostinho, A.A., Gomes L.C., Albert, J.S., Baran, E., Petrere Jr., M., Zarfl, C., Mulligan, M.Sullivan, J.P., Arantes, C.C., Sousa, L.M., Koning, A.A. , Hoeinghaus, D.J., Sabaj, M., Lundberg, J.G., Armbruster, J. , Thieme, M.L., Petry, P., Zuanon, J., Torrente Vilara, G., Snoeks, J., Ou, C., Rainboth, W., Pavanelli, C.S., Akama, A., van Soesbergen, A., Sáenz L., Stiassny, M.L.J. 2016. Balancing hydropower and biodiversity in the Amazon, Congo, and Mekong. Science 351, 128-129.

World Commission on Dams. 2000. Dams and development: a new framework for decision-making. Earthscan Publications, London, UK. 
795 Zarfl, C., Lumsdon, A.E., Berlekamp, J., Tydecks, L., Tockner, K. 2015. A global boom in hydropower dam construction. Aquatic Sciences 77, 161-170. 


\section{Figure captions}

Figure 1. Sampled sites within the Balbina Hydroelectric Reservoir in the Central

Brazilian Amazon: 25 land-bridge islands (red polygons highlighted by 1-km buffers) and five continuous forest sites $\left(\mathrm{CF}_{1}, \mathrm{CF}_{2}, \mathrm{CF}_{2 \text {-riparian, }} \mathrm{CF}_{3}\right.$ and $\mathrm{CF}_{4}$; red rectangles), placed within four mainland regions. The inset aerial photograph illustrates the archipelagic landscape (photo credit: E. M. Venticinque). The histogram represents the size distribution of Balbina islands (grey bars) and the islands included in this study (red circles).

Figure 2. Species-area relationship for lizard assemblages observed across 25 landbridge islands (left symbols) and five continuous forest (CF) sites (right symbols) surveyed at the Balbina archipelago. Shaded area represents the $95 \%$ confidence region. Boxplot indicates the median, $1^{\text {st }}$ and $3^{\text {rd }}$ quartiles, and minimum and maximum values

810 of species richness in continuous forest; solid dots indicate observed values.

Figure 3. Principal Coordinates Analysis ( $\mathrm{PCoA}$ ) ordination plot (a) based on the BrayCurtis similarity matrix of lizard composition; and (b) the relationship between island size $\left(\log _{10} \mathrm{x}\right)$ and the first PCoA axis. Circles are sized proportionally to island size $\left(\log _{10} \mathrm{x}\right)$ and colour-coded from green to red to indicate higher proportion of heliophile lizards within samples. Lizard abundances are standardized according to the sampling effort per site.

Figure 4. Relationship between the abundance $\left(\log _{10} x+1\right)$ and aggregate biomass $\left(\log _{10} \mathrm{x}\right)$ of heliophile (orange circles) and heliophobe species (green circles) and forest island area $\left(\log _{10} \mathrm{x}\right)$ within the Balbina archipelago and surrounding continuous forest.

820 Shaded area represents the $95 \%$ confidence region. Species abundances and aggregate biomass are standardized according to the sampling effort per site.

Figure 5. Rank-abundance distribution of lizards for all 30 sampled sites within the Balbina Hydroelectric Reservoir. Plots are ordered from the smallest to the largest island, followed by the continuous forest sites $\left(\mathrm{CF}_{1}-\mathrm{CF}_{4}\right)$. Green and orange circles indicate heliophobes and heliophile species, respectively. The area below the curve (red-shaded) approximately describes the overall community size for each site. Species abundances per site were standardized by sampling effort.

Figure 6. Correlation between (a) site spatial metrics and (b) lizard species traits within the Balbina archipelago and surrounding mainland continuous forest, as indicated by the scores of the RLQ axis 1. Positive and negative scores are coloured green and orange, respectively (for further details on spatial metrics and species traits, see main text and Table 1). 


\section{Tables}

835 Table 1. List of morpho-ecological species traits used to establish the relationship between those traits and the spatial metrics of sites occupied by those species: thermoregulation mode, habitat type (forest clearings and edges; terra firme forest, and forest creeks and swamps), maximum south-to-vent length (SVL), and range of prey sizes.

\begin{tabular}{|c|c|c|c|c|}
\hline Family/species & $\begin{array}{l}\text { Thermoregulation } \\
\text { mode }\end{array}$ & Habitat type & $\begin{array}{l}\text { SVL } \\
(\mathrm{mm})\end{array}$ & $\begin{array}{l}\text { Prey s } \\
(\mathrm{mm})\end{array}$ \\
\hline \multicolumn{5}{|l|}{ Gekkonidae } \\
\hline Chatogekus amazonicus & Heliophobe & Terra firme & 21.5 & $0-20$ \\
\hline Gonatodes humeralis & Heliophobe & Terra firme & 37.3 & $0-60$ \\
\hline $\begin{array}{l}\text { Pseudogonatodes } \\
\text { guianensis }\end{array}$ & Heliophobe & Creeks/swamps & 30.0 & $0-60$ \\
\hline
\end{tabular}

\section{Scincidae}

\section{Copeoglossum nigropunctatum}

\section{Iguanidae}

Norops spp. ${ }^{\mathrm{c}}$

Plica umbra

Uranoscodon

superciliosus

\section{Gymnophthalmidae}

Arthrosaura reticulata

Leposoma spp. ${ }^{\mathrm{d}}$

Tretioscincus agilis

Neusticurus bicarinatus

Prionodactylus oshaughnessyi

Ptychoglossus brevifrontalis

Bachia panoplia

\section{Teiidae}

Kentropyx spp. ${ }^{\mathrm{b}}$

Ameiva ameiva

\section{Amphisbaenidae}

Amphisbaena fuliginosa

$$
\text { Heliophile }
$$

Clearings/edges

95.0

$0->140$

Heliophobe

Heliophobe

Heliophobe

Heliophobe

Heliophobe

Heliophile

Heliophobe

Heliophobe

Heliophobe

Heliophobe

Heliophile

Heliophile

Heliophobe
Terra firme

Terra firme

Creeks/swamps

Terra firme

Terra firme

Clearings/edges

Creeks/swamps

Terra firme

Terra firme

Terra firme

Clearings/edges

Clearings/edges
$45.1 \quad 0-140$

$87.520-60$

$142.30->140$

a Trait was not available for this species. We used a general value based on the dietary items listed in Ávila-Pires (1995).

b Trait values refer to $K$. calcarata.

c Trait values refer to an average of both congeners, $N$. fuscoauratus e N. chrysolepsis.

${ }^{\mathrm{d}}$ Trait values refer to an average of both congeners, L. guianensis and L. percarinatum. 
Table 2. Set of GLMs formulated to explain lizard species richness and composition according to patch - island size $\left(\log _{10}\right.$ Area $)$ - and landscape variables - proximity $\left(\log _{10}\right.$ Prox $)$ and distance to continuous forest (Dist) - for 25 islands in the Balbina archipelagic landscape, ordered by AICc (Akaike information criterion for small samples) values. $\mathrm{K}$ corresponds to the number of parameters included in each model; $\triangle \mathrm{AICc}=\mathrm{AICc}_{\mathrm{i}}-\mathrm{AICc}_{\min }, \mathrm{i}=\mathrm{i}^{\text {th }}$ model; $\mathrm{W}_{\mathrm{i}}$ to Akaike weights (see the main text for description of the spatial metrics). Only models with $\mathrm{W}_{\mathrm{i}}>0.001$ are presented. A metric of species composition is provided by the first PCoA axis.

Parameters

\begin{tabular}{ccccccccc}
\cline { 2 - 6 } $\begin{array}{c}\text { Response } \\
\text { variable }\end{array}$ & Intercept & $\log _{\mathbf{1 0}}$ Area & $\log _{\mathbf{1 0}}$ Prox & Dist & K & AICc & $\Delta$ AICc & $\mathbf{W}_{\mathbf{i}}$ \\
\hline \multirow{2}{*}{$\begin{array}{c}\text { Species } \\
\text { richness }\end{array}$} & 0.731 & 3.100 & & & 2 & 84.5 & 0.00 & 0.606 \\
& 0.523 & 2.921 & 0.153 & & 3 & 86.9 & 2.40 & 0.182 \\
& 0.962 & 3.058 & & $<0.000$ & 3 & 87.1 & 2.55 & 0.169 \\
& 0.740 & 2.902 & 0.139 & $<0.000$ & 4 & 89.9 & 5.34 & 0.042 \\
\hline \multirow{3}{*}{ Species } & 0.319 & -0.202 & & & 2 & -7.5 & 0.00 & 0.623 \\
composition & 0.361 & -0.209 & & $<0.000$ & 3 & -5.1 & 2.45 & 0.183 \\
& 0.308 & -0.211 & 0.008 & & 3 & -4.7 & 2.81 & 0.153 \\
& 0.354 & -0.215 & 0.005 & $<0.000$ & 4 & -1.9 & 5.59 & 0.038 \\
& 0.310 & & -0.092 & & 2 & 3.4 & 10.93 & 0.003 \\
& 0.324 & & -0.094 & $<0.000$ & 3 & 6.2 & 13.76 & 0.001 \\
\hline
\end{tabular}


Table 3. Compilation of lizard island biogeography studies, including forest fragments (in tropical and subtropical forests) and true oceanic islands. We calculated the main parameters of the species-area relationship (SAR) for each study based on the power model and data provided in each study. We indicate the types of island system (continental or oceanic) and the matrix type for continental fragmented landscapes (water, pasture and plantation), number of sampled islands and their range of size,

860 maximum number of species observed $\left(\mathrm{S}_{\max }\right)$, $\mathrm{c}$ and $\mathrm{Z}$ model parameters, and corresponding $\mathrm{R}^{2}$ values.

\begin{tabular}{|c|c|c|c|c|c|c|c|}
\hline Study name (country) & No. & Range (ha) & $S_{\max }$ & c & $\mathbf{Z}$ & $\mathbf{R}^{2}$ & Source \\
\hline \multicolumn{8}{|l|}{$\begin{array}{l}\text { Continental islands (water } \\
\text { matrix) }\end{array}$} \\
\hline Balbina Reservoir (Brazil) & 25 & $1-1,466$ & 11 & 2.320 & 0.230 & 0.83 & This study \\
\hline Tucuruí Reservoir (Brazil)a & 12 & $3-2140$ & 12 & 6.924 & 0.051 & 0.42 & Lima, 2008 \\
\hline Thousand Island Lake (China) & 31 & $1-1289$ & 5 & 0.616 & 0.480 & 0.51 & Wang et al., 2009 \\
\hline \multicolumn{8}{|l|}{ Oceanic islands } \\
\hline Gulf of California (EUA) & 28 & $60-143 \mathrm{~K}$ & 10 & 1.831 & 0.135 & 0.38 & Case, 1975 \\
\hline Guam Islands (Guam) & 21 & $<1-2$ & 5 & 2.673 & 0.385 & 0.47 & Perry et al., 1998 \\
\hline \multicolumn{8}{|l|}{$\begin{array}{l}\text { Continental habitat isolates } \\
\text { (terrestrial matrix) }\end{array}$} \\
\hline \multicolumn{8}{|l|}{ Pasture } \\
\hline Regua (Brazil) & 12 & $5-272$ & 3 & 1.013 & 0.173 & 0.25 & Almeida et al., 2014 \\
\hline Los Tuxtlas (Mexico) & 6 & $1-17$ & 8 & 5.190 & 0.093 & 0.10 & $\begin{array}{l}\text { Cabrera-Guzmán } \\
\text { and Reynoso, } 2012\end{array}$ \\
\hline Lacandona (Mexico) & 9 & $3-92$ & 11 & $\begin{array}{l}14.01 \\
3\end{array}$ & -0.121 & 0.47 & Russildi et al., 2016 \\
\hline Pueblo Nuevo (Colombia) & 6 & $7-84$ & 13 & 6.308 & 0.161 & 0.88 & $\begin{array}{l}\text { Carvajal-Cogollo et } \\
\text { al., } 2008\end{array}$ \\
\hline Alta Floresta (Brazil) ${ }^{a}$ & 22 & $42-469$ & 8 & 3.896 & 0.017 & $<0.01$ & Silva, 2005 \\
\hline El Refugio (Bolivia) & 24 & $1-9$ & 8 & 3.914 & 0.180 & 0.10 & $\begin{array}{l}\text { Watling and } \\
\text { Donnelly, } 2008\end{array}$ \\
\hline \multicolumn{8}{|l|}{ Sugarcane plantation } \\
\hline Rio Grande do Norte (Brazil) & 23 & $2-27$ & 5 & 5.180 & -0.255 & 0.38 & Lion et al., 2016 \\
\hline
\end{tabular}

a Study carried out in the Brazilian Amazon forest. 

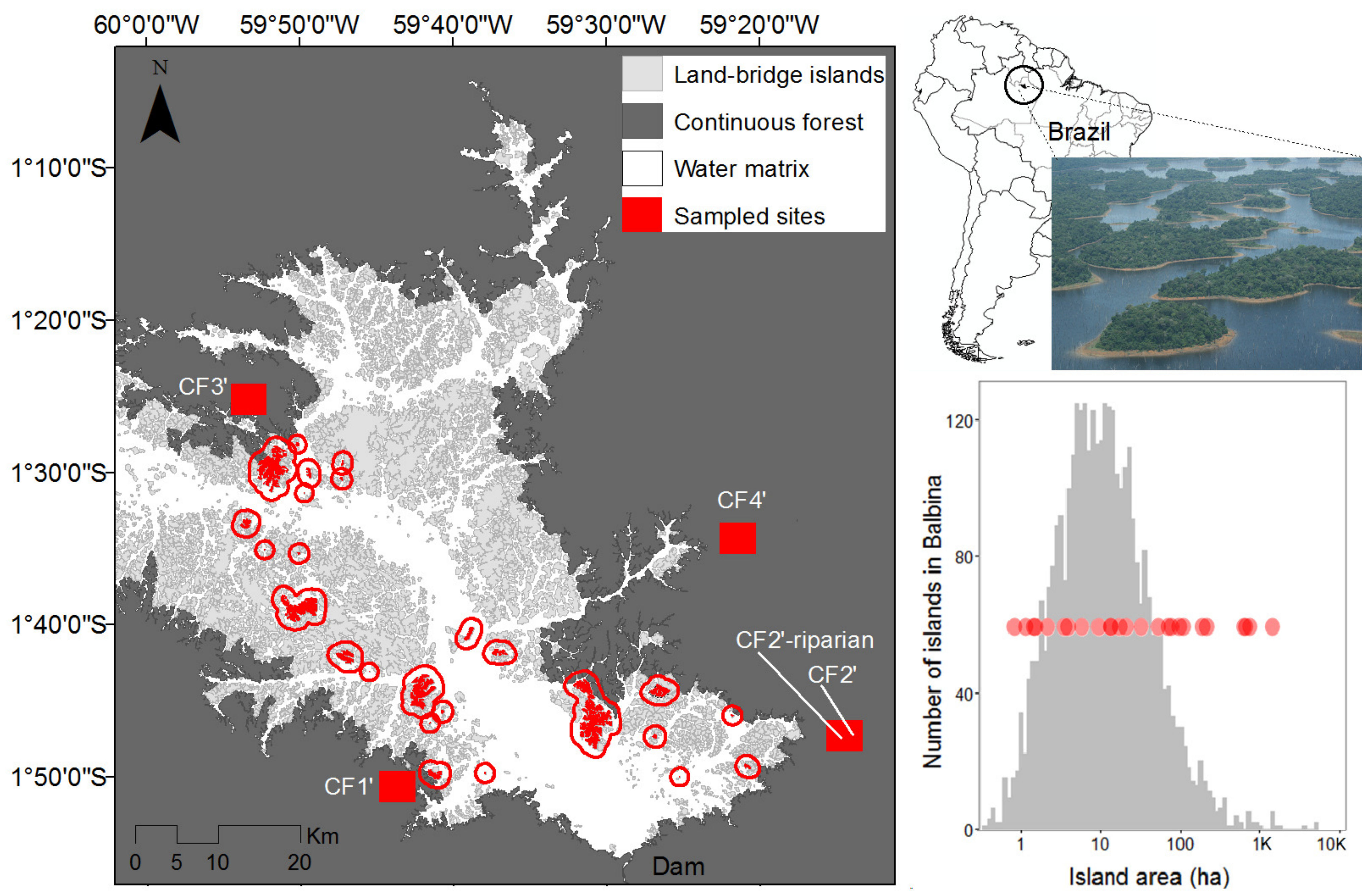

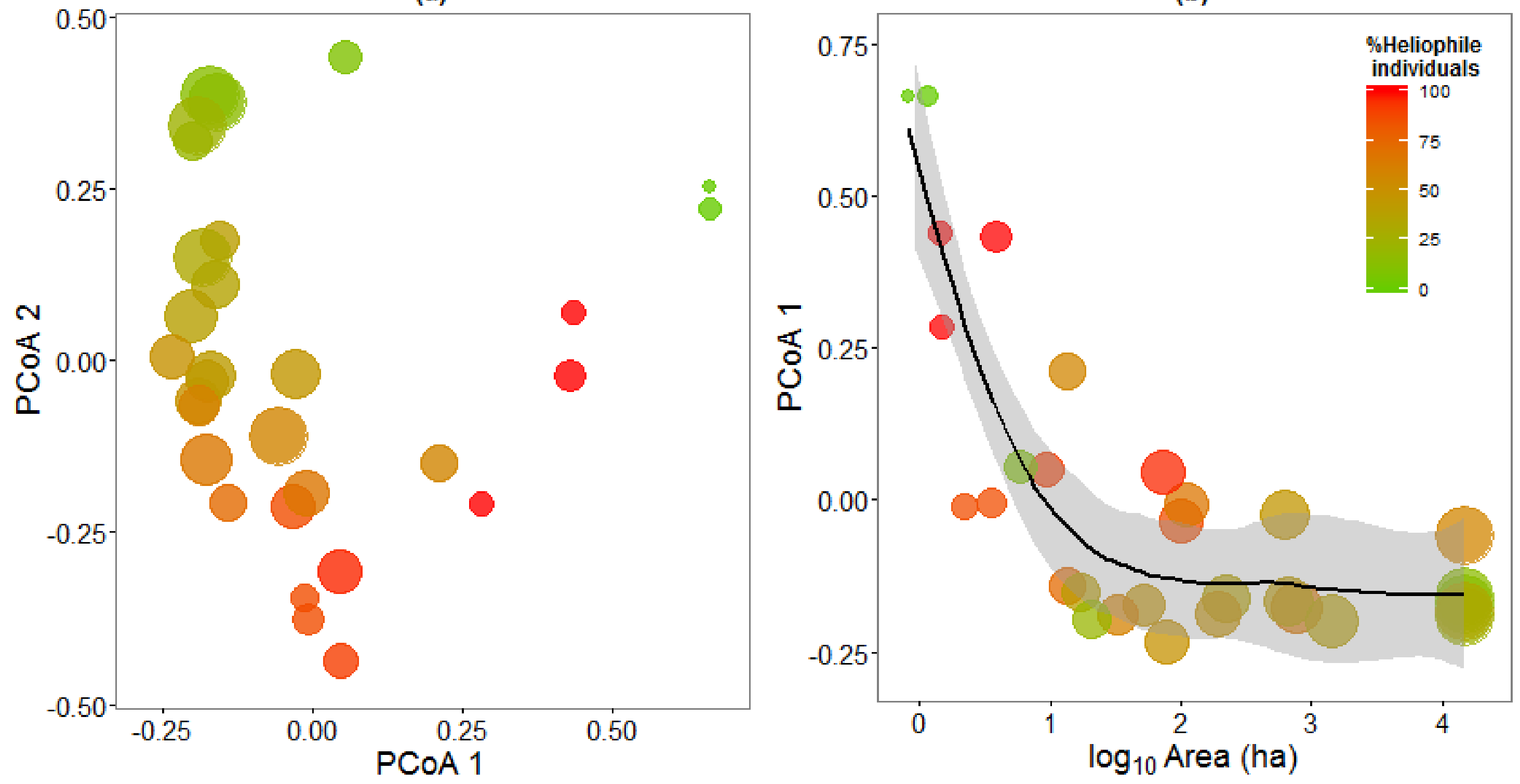
(a)

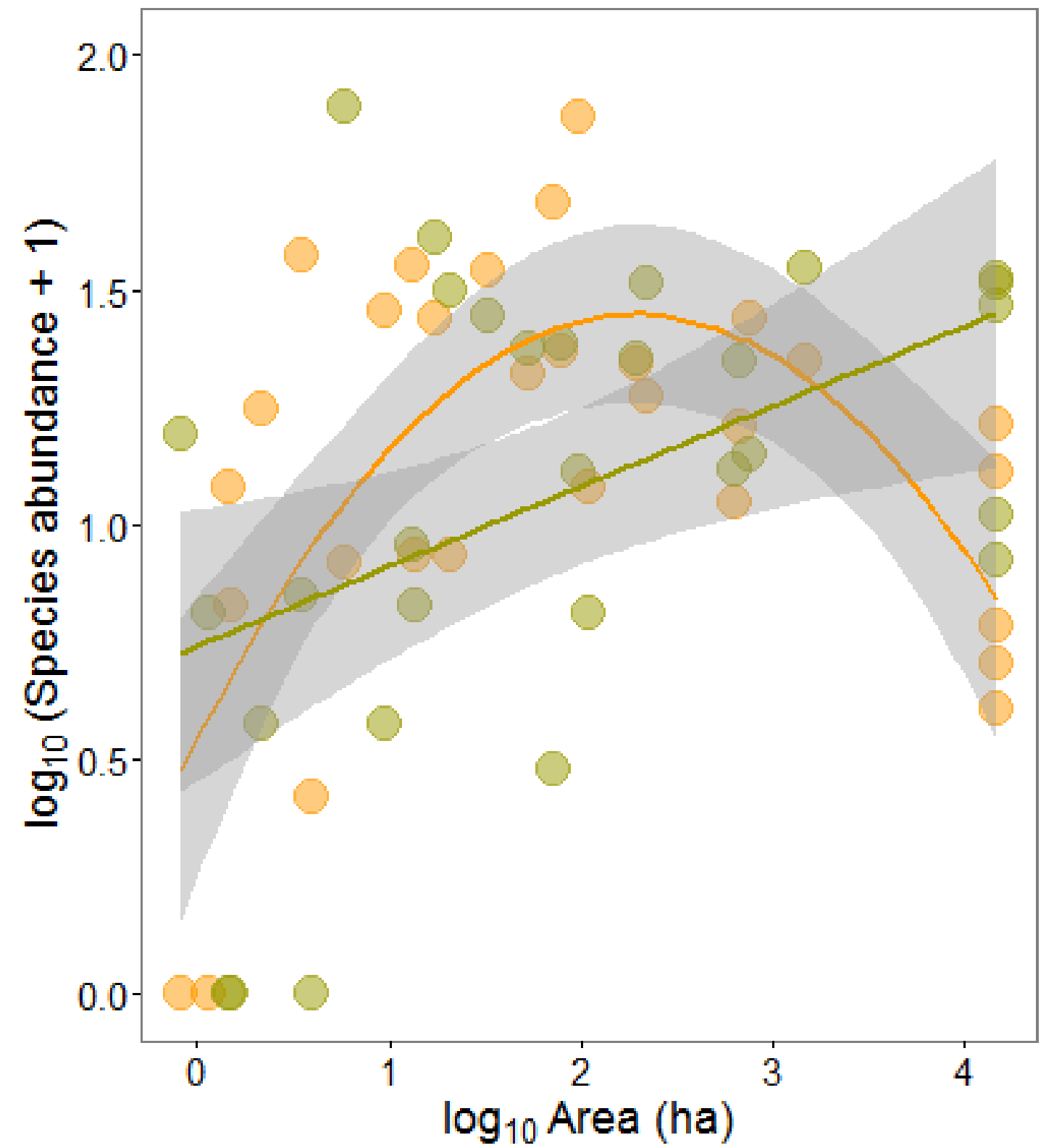

(b)

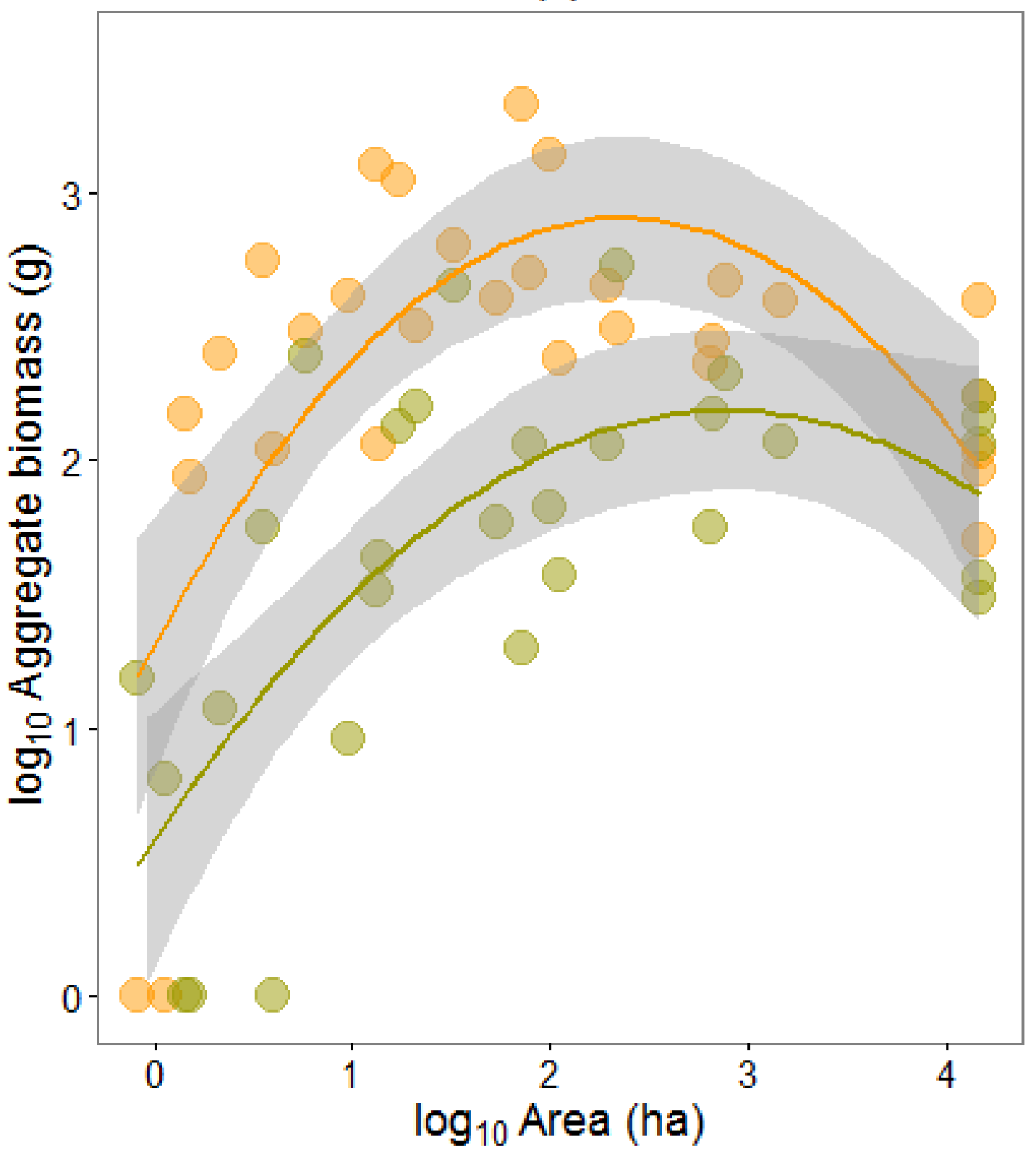




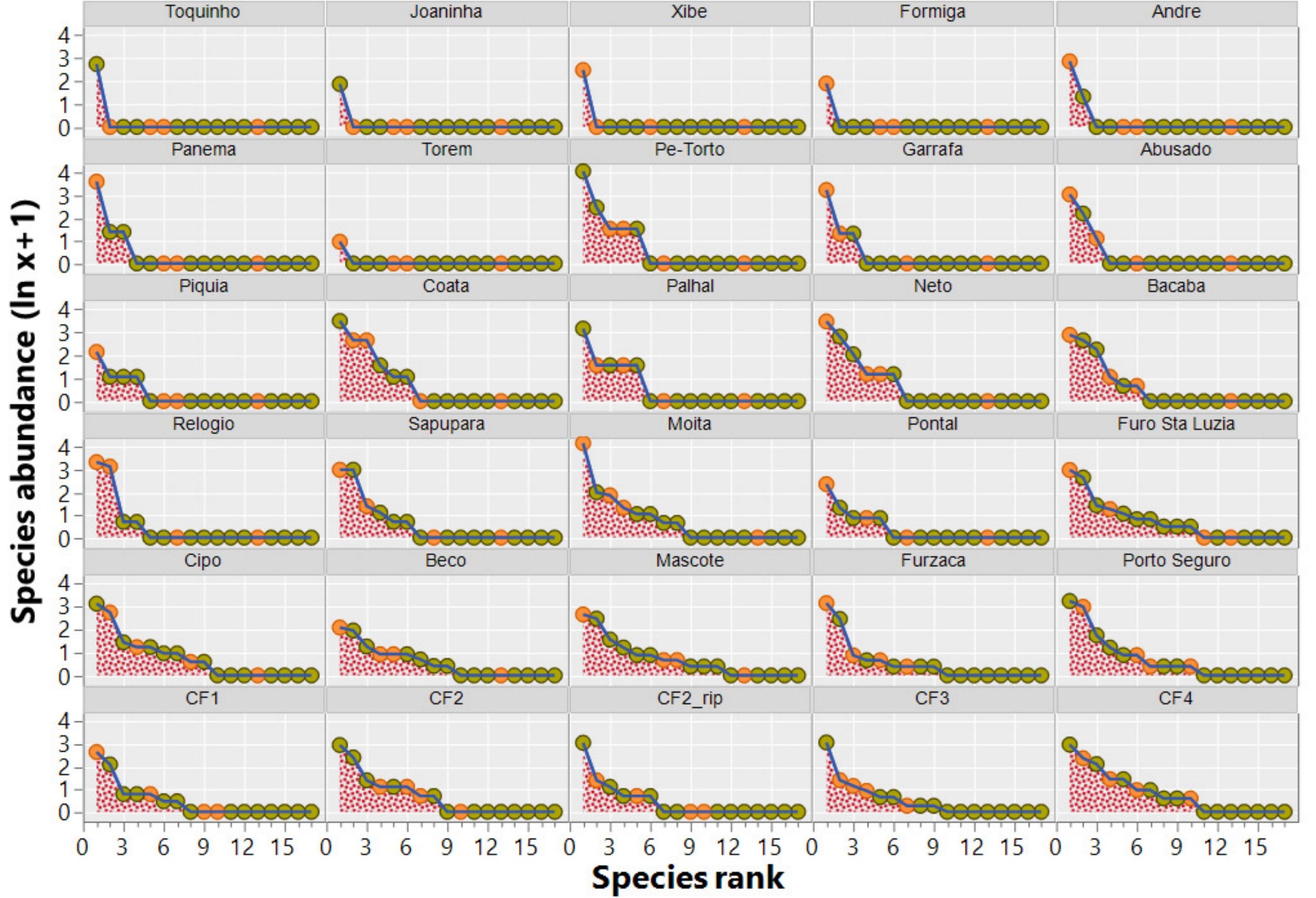


(a)

(a)

\begin{tabular}{l|l|l|} 
& & proximity \\
\hline distance & shape & pon \\
\hline
\end{tabular}

(b)

clearings/edges 


\section{Supplementary Material}

\section{Non-random lizard extinctions in land-bridge Amazonian forest islands after 28}

years of isolation

5

Ana Filipa Palmeirim ${ }^{\mathrm{a}, \mathrm{b}^{*}}$, Marcus Vinícius Vieira ${ }^{\mathrm{a}}$, Carlos A. Peres ${ }^{\mathrm{b}}$

${ }^{a}$ Laboratório de Vertebrados, Departamento de Ecologia, Universidade Federal do Rio de Janeiro, CP 68020, Rio de Janeiro RJ, CEP 21941- 590, Brazil

${ }^{\mathrm{b}}$ Centre for Ecology, Evolution and Conservation, School of Environmental Sciences, University of East Anglia, Norwich Research Park, Norwich NR4 7TJ, UK.

* Corresponding author. E-mail address: anafilipapalmeirim@gmail.com

(a)

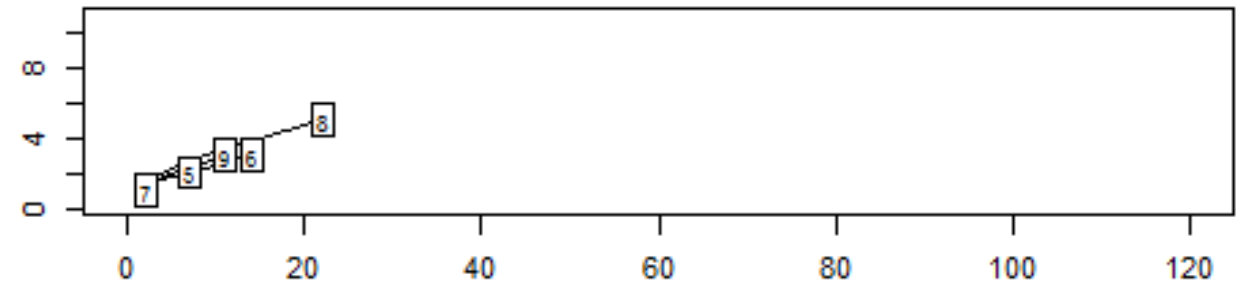

(b)

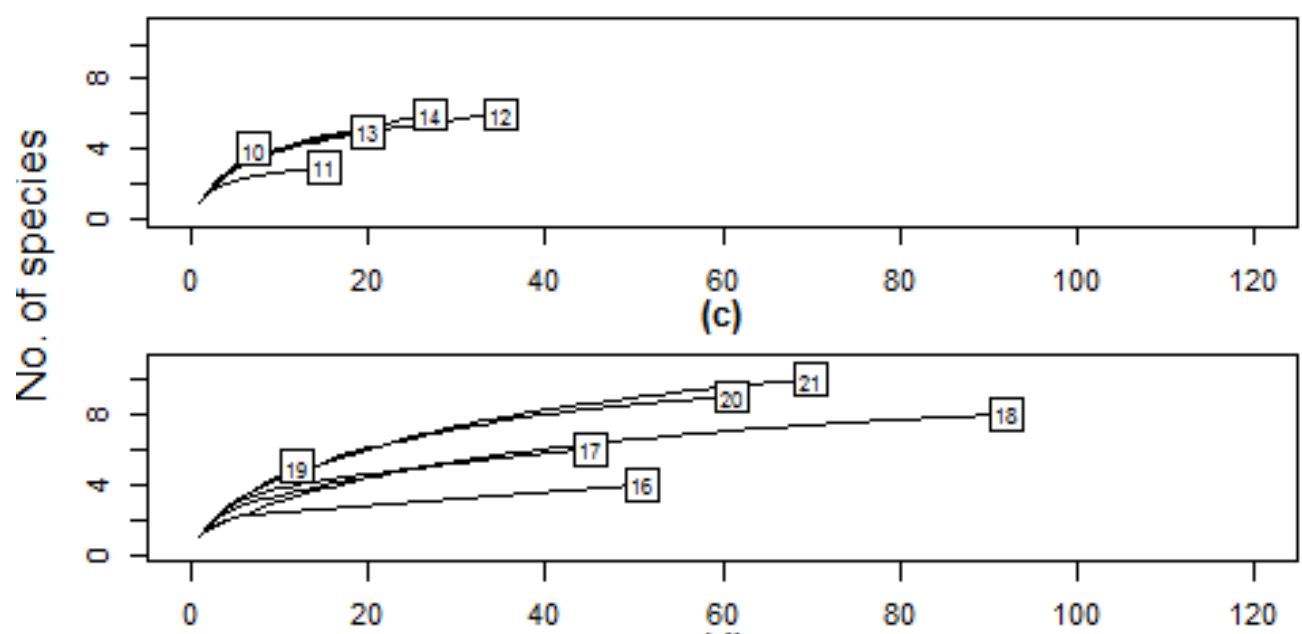

(d)

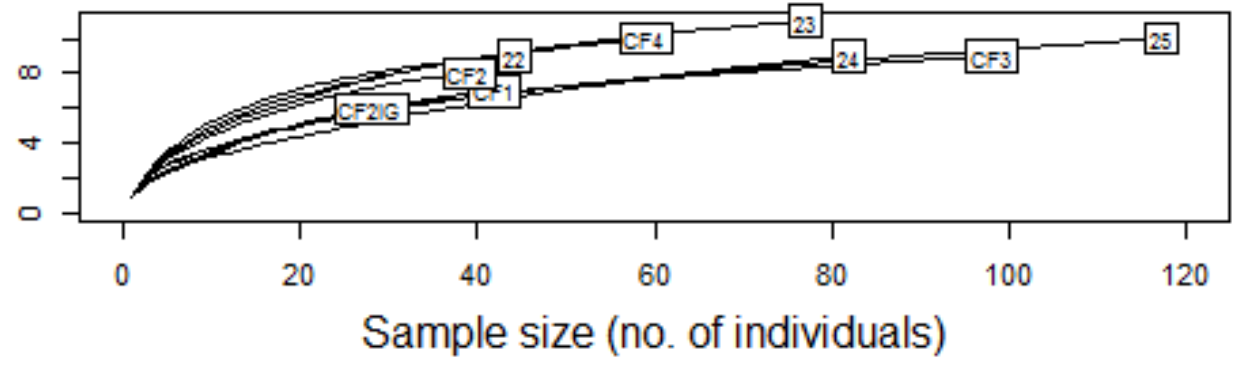

Figure A.1. Individual-based rarefaction curves for all 30 sampled sites at the Balbina

Hydroelectric Reservoir landscape, grouped according to major classes of island size:

(a) $1-50$ ha; (b) $50-200$ ha; (c) $200-500$; and (d) $>500$ ha/continuous forest sites. Sites are coded as Table 1S (for details on sampling effort per site see the main text and Table S1). 
Table A.1. Description of the sampling effort per island and continuous forest sites surveyed in the Balbina Hydroelectric Reservoir landscape of Central Brazilian Amazonia. The geographic coordinates (latitude/longitude), forest patch area, number of pitfall units deployed, corresponding number of trap-days per field campaign $\left(1^{\text {st }}\right.$ and $2^{\text {nd }}$ season) and in total, and density of traps (number of traps per hectare) are indicated for each survey site.

\begin{tabular}{|c|c|c|c|c|c|c|c|c|}
\hline \multirow{2}{*}{$\begin{array}{l}\text { Site name } \\
\quad \text { (code) }\end{array}$} & \multicolumn{2}{|c|}{ Geographic coordinates } & \multirow{2}{*}{$\begin{array}{c}\text { Area } \\
\text { (ha) }\end{array}$} & \multirow{2}{*}{$\begin{array}{l}\text { No. of } \\
\text { pitfall } \\
\text { units }\end{array}$} & \multicolumn{3}{|c|}{ No. of trap-days } & \multirow{2}{*}{$\begin{array}{r}\text { Trap } \\
\text { density }\end{array}$} \\
\hline & Lat & Long & & & $1^{\text {st }}$ & $2^{\text {nd }}$ & Total & \\
\hline Toquinho (1) & $01^{\circ} 43^{\prime} 04.8^{\prime \prime} \mathrm{S}$ & $59^{\circ} 45^{\prime} 30.1^{\prime \prime} \mathrm{W}$ & 0.8 & 1 & 14 & 11 & 25 & 1.250 \\
\hline Joaninha (2) & $01^{\circ} 31^{\prime} 20.0^{\prime \prime} \mathrm{S}$ & $59^{\circ} 49^{\prime} 43.8^{\prime \prime} \mathrm{W}$ & 1.2 & 1 & 17 & 16 & 33 & 0.833 \\
\hline Xibe (3) & $01^{\circ} 50^{\prime} 00.2^{\prime \prime} \mathrm{S}$ & $59^{\circ} 25^{\prime} 14.2^{\prime \prime} \mathrm{W}$ & 1.5 & 1 & 17 & 16 & 33 & 0.667 \\
\hline Formiga (4) & $01^{\circ} 35^{\prime} 03.6^{\prime \prime} \mathrm{S}$ & $59^{\circ} 52^{\prime} 19.2^{\prime \prime} \mathrm{W}$ & 1.5 & 1 & 16 & 16 & 32 & 0.667 \\
\hline Andre (5) & $01^{\circ} 46^{\prime} 27.3^{\prime \prime} \mathrm{S}$ & $59^{\circ} 41^{\prime} 03.9^{\prime \prime} \mathrm{W}$ & 2.2 & 2 & 34 & 32 & 66 & 0.909 \\
\hline Panema (6) & $01^{\circ} 49^{\prime} 44.5^{\prime \prime} \mathrm{S}$ & $59^{\circ} 37^{\prime} 57.2^{\prime \prime} \mathrm{W}$ & 3.5 & 2 & 28 & 32 & 60 & 0.571 \\
\hline Torem (7) & $01^{\circ} 45^{\prime} 58.8^{\prime \prime} \mathrm{S}$ & $59^{\circ} 21^{\prime} 47.5^{\prime \prime} \mathrm{W}$ & 6.1 & 2 & 81 & 144 & 225 & 0.328 \\
\hline Pe-Torto (8) & $01^{\circ} 35^{\prime} 20.0^{\prime \prime} \mathrm{S}$ & $59^{\circ} 21^{\prime} 46.7^{\prime \prime} \mathrm{W}$ & 6.6 & 2 & 32 & 18 & 50 & 0.303 \\
\hline Garrafa (9) & $01^{\circ} 27^{\prime} 55.8^{\prime \prime} \mathrm{S}$ & $59^{\circ} 50^{\prime} 14.3^{\prime \prime} \mathrm{W}$ & 10.2 & 2 & 34 & 32 & 66 & 0.196 \\
\hline Abusado (10) & $01^{\circ} 30^{\prime} 24.0^{\prime \prime} \mathrm{S}$ & $59^{\circ} 47^{\prime} 17.5^{\prime \prime} \mathrm{W}$ & 13.9 & 3 & 48 & 48 & 96 & 0.216 \\
\hline Piquia (11) & $01^{\circ} 45^{\prime} 42.5^{\prime \prime} \mathrm{S}$ & $59^{\circ} 40^{\prime} 43.2^{\prime \prime} \mathrm{W}$ & 16.5 & 3 & 42 & 48 & 90 & 0.182 \\
\hline Coata (12) & $01^{\circ} 29^{\prime} 22.1^{\prime \prime} \mathrm{S}$ & $59^{\circ} 47^{\prime} 13.6^{\prime \prime} \mathrm{W}$ & 18.4 & 3 & 48 & 48 & 96 & 0.163 \\
\hline Palhal (13) & $01^{\circ} 47^{\prime} 21.5^{\prime \prime} \mathrm{S}$ & $59^{\circ} 26^{\prime} 50.6^{\prime \prime} \mathrm{W}$ & 25.8 & 3 & 48 & 48 & 96 & 0.116 \\
\hline Neto (14) & $01^{\circ} 49^{\prime} 20.0^{\prime \prime} \mathrm{S}$ & $59^{\circ} 20^{\prime} 47.9^{\prime \prime} \mathrm{W}$ & 32.8 & 3 & 48 & 33 & 81 & 0.091 \\
\hline Bacaba (15) & $01^{\circ} 30^{\prime} 01.0^{\prime \prime} \mathrm{S}$ & $59^{\circ} 49^{\prime} 24.5^{\prime \prime} \mathrm{W}$ & 53.6 & 6 & 96 & 96 & 192 & 0.112 \\
\hline Relogio (16) & $01^{\circ} 40^{\prime} 35.2^{\prime \prime} \mathrm{S}$ & $59^{\circ} 38^{\prime} 57.8^{\prime \prime} \mathrm{W}$ & 85.0 & 6 & 84 & 96 & 180 & 0.071 \\
\hline Sapupara(17) & $01^{\circ} 41^{\prime} 49.5^{\prime \prime} \mathrm{S}$ & $59^{\circ} 37^{\prime} 00.8^{\prime \prime} \mathrm{W}$ & 98.5 & 6 & 84 & 96 & 180 & 0.061 \\
\hline Moita (18) & $01^{\circ} 33^{\prime} 20.9^{\prime \prime} \mathrm{S}$ & $59^{\circ} 53^{\prime} 31.9^{\prime \prime} \mathrm{W}$ & 105.8 & 6 & 102 & 96 & 198 & 0.057 \\
\hline Pontal (19) & $01^{\circ} 49^{\prime} 49.9^{\prime \prime} \mathrm{S}$ & $59^{\circ} 41^{\prime} 12.8^{\prime \prime} \mathrm{W}$ & 125.9 & 6 & 30 & 102 & 132 & 0.048 \\
\hline $\begin{array}{l}\text { Furo Sta } \\
\text { Luzia (20) }\end{array}$ & $01^{\circ} 42^{\prime} 05.0^{\prime \prime} \mathrm{S}$ & $59^{\circ} 47^{\prime} 00.7^{\prime \prime} \mathrm{W}$ & 213.5 & 9 & 126 & 99 & 225 & 0.042 \\
\hline Cipo (21) & $01^{\circ} 44^{\prime} 22.5^{\prime \prime} \mathrm{S}$ & $59^{\circ} 26^{\prime} 31.2^{\prime \prime} \mathrm{W}$ & 218.1 & 9 & 144 & 144 & 288 & 0.041 \\
\hline $\operatorname{Beco}(22)$ & $01^{\circ} 44^{\prime} 20.0^{\prime \prime} \mathrm{S}$ & $59^{\circ} 42^{\prime} 06.1^{\prime \prime} \mathrm{W}$ & 688.9 & 12 & 168 & 192 & 360 & 0.017 \\
\hline Mascote (23) & $01^{\circ} 38^{\prime} 53.6^{\prime \prime} \mathrm{S}$ & $59^{\circ} 50^{\prime} 00.0^{\prime \prime} \mathrm{W}$ & 730.6 & 12 & 192 & 192 & 384 & 0.016 \\
\hline Furzaca (24) & $01^{\circ} 29^{\prime} 40.6^{\prime \prime} \mathrm{S}$ & $59^{\circ} 51^{\prime} 48.0^{\prime \prime} \mathrm{W}$ & 1012.4 & 12 & 198 & 192 & 390 & 0.012 \\
\hline $\begin{array}{l}\text { Porto Seguro } \\
\text { (25) }\end{array}$ & $01^{\circ} 46^{\prime} 00.4^{\prime \prime} \mathrm{S}$ & $59^{\circ} 30^{\prime} 55.9^{\prime \prime} \mathrm{W}$ & 1466.0 & 12 & 192 & 192 & 384 & 0.008 \\
\hline $\mathrm{CF}_{1}(26)$ & $01^{\circ} 49^{\prime} 49.1^{\prime \prime} \mathrm{S}$ & $59^{\circ} 42^{\prime} 02.5^{\prime \prime} \mathrm{W}$ & $\infty$ & 18 & 0 & 306 & 306 & $0.001^{\mathrm{a}}$ \\
\hline $\mathrm{CF}_{2}(27)$ & $01^{\circ} 47^{\prime} 22.6^{\prime \prime} \mathrm{S}$ & $59^{\circ} 14^{\prime} 52.1^{\prime \prime} \mathrm{W}$ & $\infty$ & 12 & 180 & 0 & 180 & $0.001^{\mathrm{a}}$ \\
\hline $\begin{array}{l}\mathrm{CF}_{\text {2-riparian }} \\
(28)\end{array}$ & $01^{\circ} 47^{\prime} 22.6^{\prime \prime} \mathrm{S}$ & $59^{\circ} 14^{\prime} 52.1^{\prime \prime} \mathrm{W}$ & $\infty$ & 12 & 180 & 0 & 180 & $0.001^{\mathrm{a}}$ \\
\hline $\mathrm{CF}_{3}(29)$ & $01^{\circ} 26^{\prime} 02.3^{\prime \prime} \mathrm{S}$ & $59^{\circ} 54^{\prime} 28.8^{\prime \prime} \mathrm{W}$ & $\infty$ & 18 & 306 & 288 & 594 & $0.001^{\mathrm{a}}$ \\
\hline $\mathrm{CF}_{4}(30)$ & $01^{\circ} 34^{\prime} 33.6^{\prime \prime} \mathrm{S}$ & $59^{\circ} 23^{\prime} 25.2^{\prime \prime} \mathrm{W}$ & $\infty$ & 15 & 0 & 225 & 225 & $0.001^{\mathrm{a}}$ \\
\hline
\end{tabular}

$25{ }^{\text {a }}$ For analytical purposes, these CF sites were attributed an arbitrary area of 14,660 haequivalent to one order of magnitude larger than the largest surveyed island. 
Table A.2. Model fitting of the lizard species-area relationship (SAR) for all 25 surveyed islands in Balbina Hydroelectric Reservoir, using both the power and semi-log SAR models, ordered according to the Akaike Information Criteria (AIC). For each model, we indicate its equation, values for the parameters $c$ and $z$, and the corresponding explanation power $\left(\mathrm{R}^{2}\right)$.

\begin{tabular}{llllll}
\hline Model & Formula & $\mathbf{c}$ & $\mathbf{z}$ & $\mathbf{R}^{\mathbf{2}}$ & AIC \\
\hline Power & c x Area $^{\mathrm{z}}$ & 2.32 & 0.23 & 0.827 & 91.04 \\
Exponential & $\mathrm{c}+\mathrm{z} \log _{10}$ (Area) & 1.35 & 0.73 & 0.870 & 83.39 \\
\hline
\end{tabular}

Table A.3. Mean body mass values of lizard species, obtained from the literature. Whenever species body mass data were unavailable, body mass was assumed to be equivalent to another closely related species of the same genus or based on a species with a comparable maximum SVL, as indicated in parentheses.

\begin{tabular}{lll}
\hline \multicolumn{1}{c}{ Species } & Body mass (g) & Source \\
\hline Ameiva ameiva & 67.60 & Vitt and Zani 1998 \\
Amphisbaena fuliginosa & 166.50 & Andrade et al., 2006 (Amphisbaena alba) \\
Arthrosaura reticulata & 3.90 & Camacho et al., 2016 \\
Bachia panoplia & 3.11 & Ramos-Pallares et al., 2015 (Bachia \\
Chatogekus amazonicus & 0.50 & bicolor) \\
Copeoglossum nigropunctatum & 13.30 & Vitt and Zani, 1998 \\
Gonatodes humeralis & 0.98 & Vitt and Zani, 1998 \\
Kentropyx sp. & 15.08 & Vitt and Zani, 1998 \\
Leposoma sp. & 0.58 & Vitt, 1991 \\
Neusticurus bicarinatus & 16.30 & Vitt and Zani, 1998 \\
Norops sp. & 2.91 & Camacho et al., 2016 \\
Plica umbra & 17.60 & Vitt and Zani, 1998 \\
Prionodactylus oshaughnessyi & 3.90 & Vitt et al., 1997 \\
Pseudogonatodes guianensis & 0.50 & (Arthrosaura reticulata) \\
Ptychoglossus brevifrontalis & 3.90 & (Chatogekus amazonicus) \\
Tetrioscincus agilis & 3.10 & Ramos-Pallares et al. 2010 (Ptychoglossus \\
Uranoscodon superciliosus & 47.40 & bicolor) \\
40 & & Camacho et al., 2016 \\
\end{tabular}
40

\section{Reference List}

Andrade, D.V., Nascimento, L.B., Abe, A.S. 2006. Habits hidden underground: a review on the reproduction of the Amphisbaenia with notes on four neotropical species. Amphibia-Reptilia 27, 207-217.

Camacho, A., Recoder, R., Teixeira, M., Kohlsdorf, T., Rodrigues, M.T., Lee, M.S. 2016. Overcoming phylogenetic and geographic uncertainties to test for correlates of range size evolution in gymnophthalmid lizards. Ecography 39, 001-010.

Ramos-Pallares, E., Serrano-Cardozo, V.H., Ramírez-Pinilla, M.P. 2010. Reproduction of Ptychoglossus bicolor (Squamata: Gymnophthalmidae) in an Andean coffee 
shade plantation in Colombia. South American Journal of Herpetology 5, 143150.

Ramos-Pallares, E., Anaya-Rojas, J.M., Serrano-Cardozo, V.H., Ramírez-Pinilla, M.P. 2015. Feeding and Reproductive Ecology of Bachia bicolor (Squamata: Gymnophthalmidae) in Urban Ecosystems from Colombia. Journal of Herpetology 49, 108-117.

Vitt, L.J., Zani, P.A. 1998. Ecological relationships among sympatric lizards in a transitional forest in the northern Amazon of Brazil. Journal of Tropical Ecology 14, 63-86.

Vitt, L.J., Zani, P.A., Lima, A.C.M. 1997. Heliotherms in tropical rain forest: the ecology of Kentropyx calcarata (Teiidae) and Mabuya nigropunctata (Scincidae) in the Curuá-Una of Brazil. Journal of Tropical Ecology 13, 199-220.

Vitt, L.J. 1991. Ecology and life history of the wide-foraging lizard Kentropyx calcarata (Teiidae) in Amazonian Brazil. Canadian Journal of Zoology 69, 2791-2799.

Table A.4. GLMs explaining the abundance $\left(\log _{10} \mathrm{x}+1\right)$ and aggregate biomass $\left(\log _{10}\right.$ $\mathrm{x})$ of heliophile and heliophobe species according to (1) forest area $\left(\log _{10} \mathrm{x}\right)$ and to (2) both forest area and its quadratic term. AIC values are provided for each model.

\begin{tabular}{llll}
\hline $\begin{array}{l}\text { Response } \\
\text { variable }\end{array}$ & $\begin{array}{l}\text { Therm. } \\
\text { mode }\end{array}$ & Model parameters & AIC \\
\hline $\log _{10}($ Species & Heliophile & (1) Intercept $+\log _{10}$ Area & 41.760 \\
abundance +1$)$ & & (2) Intercept $+\log _{10}$ Area $+\log _{10}$ Area $^{2}$ & 24.799 \\
& Heliophobe & (1) Intercept $+\log _{10}$ Area & 40.948 \\
& & (2) Intercept $+\log _{10}$ Area $+\log _{10}$ Area $^{2}$ & 40.069 \\
\hline $\log _{10}$ Aggregate & Heliophile & (1) Intercept $+\log _{10}$ Area & 70.192 \\
biomass & & (2) Intercept $+\log _{10}$ Area $+\log _{10}$ Area $^{2}$ & 52.756 \\
& Heliophobe & (1) Intercept $+\log _{10}$ Area & 61.127 \\
& & (2) Intercept $+\log _{10}$ Area $+\log _{10}$ Area $^{2}$ & 52.83 \\
\hline
\end{tabular}

Table A.5. 'Best' GLM model results explaining the species richness and species composition of lizards across 25 land-bridge islands within the Balbina Hydroelectric Reservoir landscape. The estimate, standard error, and $\mathrm{Z}$ and $\mathrm{P}$ values are indicated for the intercept and the patch metric included in the model. Species composition is represented by the first PCoA axis (for details on model selection see main text and Table 2).

\begin{tabular}{llllll}
\hline $\begin{array}{l}\text { Response } \\
\text { variable }\end{array}$ & $\begin{array}{l}\text { Explanatory } \\
\text { variables }\end{array}$ & Estimate & SE & $\boldsymbol{t}$-value & $\boldsymbol{P}(>|\mathbf{z}|)$ \\
\hline $\begin{array}{l}\text { Species } \\
\text { richness }\end{array}$ & Intercept & 0.731 & 0.428 & 1.706 & 0.102 \\
\hline $\log _{10}$ Area & 3.100 & 0.250 & 12.421 & $<0.000$ \\
\hline Species & Intercept & 0.319 & 0.068 & 4.693 & $<0.000$ \\
\hline
\end{tabular}

Table A.6. GLM models explaining species abundance $\left(\log _{10} x+1\right)$ and aggregate biomass $\left(\log _{10}\right)$ of heliophile and heliophobe lizard species in relation to island area 
$\left(\log _{10}\right)$ for all 25 land-bridge islands and five continuous forest sites surveyed (i.e. 14638 ha).

\begin{tabular}{|c|c|c|c|c|c|c|}
\hline $\begin{array}{l}\text { Response } \\
\text { variable }\end{array}$ & $\begin{array}{l}\text { Therm. } \\
\text { mode }\end{array}$ & $\begin{array}{l}\text { Explanatory } \\
\text { variables }\end{array}$ & Estimate & SE & $t$-value & $P(>|\mathbf{z}|)$ \\
\hline \multirow{5}{*}{$\begin{array}{l}\log _{10} \\
\text { (Species } \\
\text { abundance } \\
+1)\end{array}$} & \multirow{3}{*}{ Heliophile } & Intercept & 0.545 & 0.146 & 3.730 & $<0.000$ \\
\hline & & $\log _{10}$ Area & 0.789 & 0.162 & 4.854 & $<0.000$ \\
\hline & & $\log _{10}$ Area $^{2}$ & -0.172 & 0.036 & -4.760 & $<0.000$ \\
\hline & \multirow{2}{*}{ Heliophobe } & Intercept & 0.742 & 0.141 & 5.245 & $<0.000$ \\
\hline & & $\log _{10}$ Area & 0.170 & 0.061 & 2.784 & 0.010 \\
\hline \multirow{6}{*}{$\begin{array}{l}\log _{10} \\
\text { Aggregate } \\
\text { biomass }\end{array}$} & \multirow{3}{*}{ Heliophile } & Intercept & 1.308 & 0.233 & 5.619 & $<0.000$ \\
\hline & & $\log _{10}$ Area & 1.351 & 0.259 & 5.218 & $<0.000$ \\
\hline & & $\log _{10}$ Area $^{2}$ & -0.286 & 0.058 & -4.961 & $<0.000$ \\
\hline & \multirow{3}{*}{ Heliophobe } & Intercept & 0.580 & 0.233 & 2.490 & 0.019 \\
\hline & & $\log _{10}$ Area & 1.110 & 0.260 & 4.282 & $<0.000$ \\
\hline & & $\log _{10}$ Area $^{2}$ & -0.192 & 0.058 & -3.325 & 0.003 \\
\hline
\end{tabular}

Table A.7. Results of the RLQ analysis of species traits (Q), spatial metrics (R) and abundances of lizard species (L) across 25 forest islands and five mainland continuous forest sites in the Balbina Hydroelectric Reservoir landscape. We present the eigenvalues (and \% of total co-inertia) for the first two axes separately for each ordination of tables R (principal components analysis - PCA), L (correspondence analysis - CA) and Q (PCA; a); and, eigenvalues and percentage of total co-inertia accounted for by the first two RLQ axes and covariance (b).

Axis $1(\%) \quad$ Axis $2(\%)$

(a)

\begin{tabular}{llll} 
Separate & R matrix PCA & $2.93(73.36)$ & $0.73(18.24)$ \\
ordinations & L matrix CA & $0.50(26.63)$ & $0.42(21.96)$ \\
& Q matrix PCA (Hill-Smith) & $3.31(66.14)$ & $1.01(20.16)$ \\
\hline
\end{tabular}

(b)
RLQ analysis
RLQ axis eigenvalues
0.48 (94.57)
$0.03(5.11)$

Covariance

0.69

0.16 